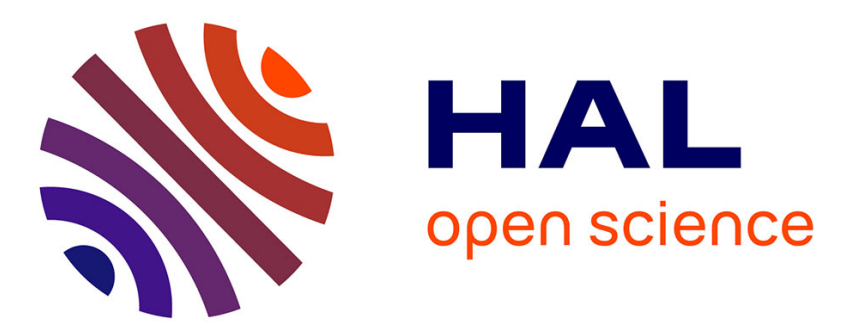

\title{
A long way from New York City: Socially stratified contact-induced phonological convergence in Ganluo Ersu (Sichuan, China)
}

\author{
Katia Chirkova, James N Stanford, Dehe Wang
}

\section{- To cite this version:}

Katia Chirkova, James N Stanford, Dehe Wang. A long way from New York City: Socially stratified contact-induced phonological convergence in Ganluo Ersu (Sichuan, China). Language Variation and Change, In press. hal-01684078

\section{HAL Id: hal-01684078 https://hal.science/hal-01684078}

Submitted on 15 Jan 2018

HAL is a multi-disciplinary open access archive for the deposit and dissemination of scientific research documents, whether they are published or not. The documents may come from teaching and research institutions in France or abroad, or from public or private research centers.
L'archive ouverte pluridisciplinaire HAL, est destinée au dépôt et à la diffusion de documents scientifiques de niveau recherche, publiés ou non, émanant des établissements d'enseignement et de recherche français ou étrangers, des laboratoires publics ou privés. 
A long way from New York City:

Socially stratified contact-induced phonological convergence in Ganluo Ersu

(Sichuan, China)

Authors:

1. Katia Chirkova (CNRS, France)

2. James N. Stanford (Dartmouth College, USA)

3. Dehe Wang (Xichang College, China)

Corresponding author:

James N. Stanford

6220 Reed Hall

Dartmouth College

Hanover, NH 03784

Ph. (603)646-0099

James.N.Stanford@Dartmouth.edu 


\section{ABSTRACT}

Labov's classic study, The Social Stratification of English in New York City (1966), paved the way for generations of researchers to examine sociolinguistic patterns in many different communities (Bell, Sharma, \& Britain, 2016). This research paradigm has traditionally tended to focus on Western industrialized communities and large world languages and dialects, leaving many unanswered questions about lesserstudied indigenous minority communities. In this study, we examine whether Labovian models for age, sex, and social stratification (Labov, 1966, 2001; Trudgill, 1972, 1974) may be effectively applied to a small, endangered Tibeto-Burman language in southwestern China: Ganluo Ersu. Using new field recordings with 97 speakers, we find evidence of phonological change in progress as Ganluo Ersu consonants are converging toward Chinese phonology. The results suggest that when an endangered language undergoes convergence toward a majority language due to intense contact, this convergence is manifested in a socially stratified way that is consistent with many of the predictions of the classic Labovian sociolinguistic principles.

\section{INTRODUCTION}

This paper documents and analyzes consonant variation among 97 speakers of Ganluo Ersu (52 women, 45 men, ages 8-94), an endangered Tibeto-Burman language in southwestern China. Ganluo Ersu was traditionally spoken in a multilingual setting in contact with two distinct Sino-Tibetan languages: Nuosu (or Yi, Lolo-Burmese, Tibeto-Burman) and Southwestern Mandarin Chinese (西南官话 xīnán guānhuà, Sinitic, hereafter Mandarin) (e.g., Wu Da, 2004, 2015). Since the launching of Chinese economic reforms in the late 1970s, one of these contact languages, 
Mandarin, has become prestigious and dominant in the Ganluo Ersu community through intense contact with industrialized Chinese culture and language. The transition toward this unequal prestige relationship between contact languages has led to considerable variation and change in Ganluo Ersu. In the present study, we focus on four variables: (1) loss of retroflexes, (2) delateralization of the lateral fricative ([1] $\sim[\mathrm{x}]$ ), (3) devoicing of stops and affricates (e.g., $[\mathrm{b}] \sim[\mathrm{p}]$ ), and (4) simplification of onsets (e.g., $[\mathrm{mb}] \sim[\mathrm{b}])$. The observed patterns of variation suggest a trend of Ersu phonological convergence toward Mandarin, that is, the adjustment of the inventory of sounds in Ganluo Ersu to more closely match that of Mandarin. Our data furthermore suggest that the way that phonological convergence manifests itself is socially constrained and stratified, involving quantifiable factors of age, occupation, education, and speaker sex.

Our data lend insight into two key areas at the intersection of contact linguistics and sociolinguistics. First, our data contribute to the understanding of the role of socioeconomic stratification and other social factors in the process of contactinduced convergence. The significance of social factors in convergence in general and phonological convergence in particular has long been recognized in contact linguistics (e.g., Clyne, 2003:104-105, 115-116; Fishman, 1991; Grenoble \& Whaley, 1998; Matras, 2009:223-226; Poplack \& Levey, 2010; Thomason, 2008, 2009; Thomason \& Kaufman, 1988; Winford, 2003:54-56; inter alia). However, the empirical and theoretical ramifications in relation to phonological convergence in an endangered language, as in our study, are rarely interpreted from a quantitative variationist sociolinguistic perspective. Our Ganluo Ersu study helps fill this gap.

Second, our case study probes the generalizability of principles central to sociolinguistic theory, specifically, a correlation of patterns of linguistic variation 
with the social stratification of speech communities (Labov, 1966, 2001; Trudgill, 1972, 1974), in relation to a lesser-studied language. Ganluo Ersu villages (Figure 1) are far removed from the large Western urban centers where many classic sociolinguistic principles were founded. Located near the edge of the Tibetan plateau in Sichuan province, the Ganluo Ersu language community differs drastically from New York City_-geographically, socially, and linguistically. Can Labovian principles be effectively applied in such a setting? Are those principles relevant? Or are the society types simply too different? Labov (2016) discusses the need to examine these questions:

Though my New York City study was generally well received, I noted in the years that followed a tendency to regard it as a claim that class stratification of linguistic variables, measured by occupation, education, and income, would be found everywhere in the world. Of course, no such claim was intended. In fact, I wondered whether the techniques we had developed for the study of variation in the Western metropolis... would have any application to the study of little-known languages where the linguist is under an imperative to describe the basic elements and structures before the object of description disappears (586).

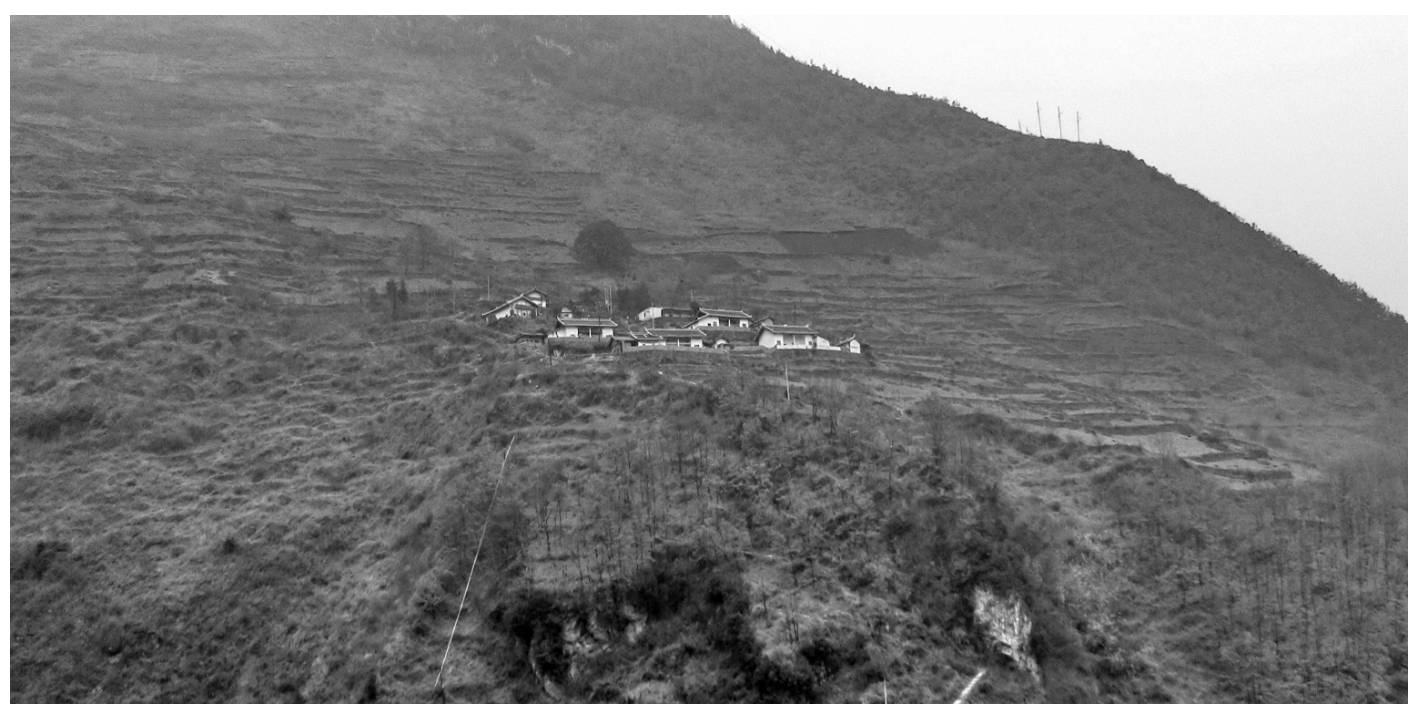

FIGURE 1. A long way from New York City: a small Ganluo Ersu village in rural Sichuan province, western China. 
In prior studies of indigenous languages, researchers have encountered situations where local social structures differ from Western industrialized societies to the extent that some Labovian principles are difficult to apply. Stanford $(2008,2009)$ finds that rural Sui communities of Guizhou province have a strong sense of clan identity that provides the most important social patterns, not socioeconomic strata. Rural rice-farming Sui communities are relatively egalitarian, and clan-level linguistic variation far outweighs any patterns of sociolinguistic stratification. Likewise, Clarke (2009) shows that the social patterns of the Sheshatshiu Innu of Labrador, Canada, do not naturally fit this part of the Labovian paradigm: "a classification scheme grounded in socioeconomic stratification, as per urban variationist studies (e.g., Labov, 1966), was almost totally irrelevant" (Clarke, 2009:113). Even so, she found evidence of other types of stratification: three territorial groups that showed varying levels of prestige. For Sheshatshiu Innu, socioeconomic status was not the crucial factor, but the community nonetheless had speech patterns that correlated with locally relevant social structure. This suggests a significant contrast in sociolinguistic patterns between the commonly studied urban Western communities and lesser-studied nonWestern indigenous minority communities. But what happens to those patterns when an indigenous minority community undergoes intense contact with a majority language? Our Ganluo Ersu study shows that when contact-induced phonological convergence occurs in an unequal prestige relationship, the convergence can be realized in terms of socially stratified, quantifiable variation. This suggests that classical Labovian sociolinguistic principles for age, sex, and social class (Labov, 1996, 2001; Trudgill, 1972, 1974) may also be applicable to the study of a small indigenous community such as Ersu. 
The remainder of the paper is structured as follows. We first provide background information on the Ersu people and their language. Following this, we introduce the study site and methods of data collection and analysis. We then discuss the results, summarize the findings of the study, and consider potential avenues for future research. The paper concludes with an appendix that provides the word list used for data collection.

\section{BACKGROUND ON ERSU}

Ersu (/áv-sý xò/, 尔苏语 ěrsūyǔ, ISO-639 code ers) is a little-studied Tibeto-Burman language spoken in rural areas of Southwest China. Ersu is classified as a member of the Qiangic subgroup of Tibeto-Burman (see Bradley, 1997:36-37; Chirkova, 2012; Sun, 1983, 2001). It is spoken by approximately 8,000 people from an overall ethnic population of ca. 16,800 people in four counties in Sichuan Province (四川省) in the People's Republic of China (PRC) (Sun, 1982, 1983; Wang, 2010:207; Zhang, 2013:3-29). As Figure 2 shows, the four counties in which Ersu speakers reside are: Ganluo (甘洛县) and Yuexi (越西县) in Liangshan Yi Autonomous Prefecture (凉山 彝族自治州); and Shimian (石棉县) and Hanyuan (汉源县) in Ya'an Municipality ( 雅安市). 


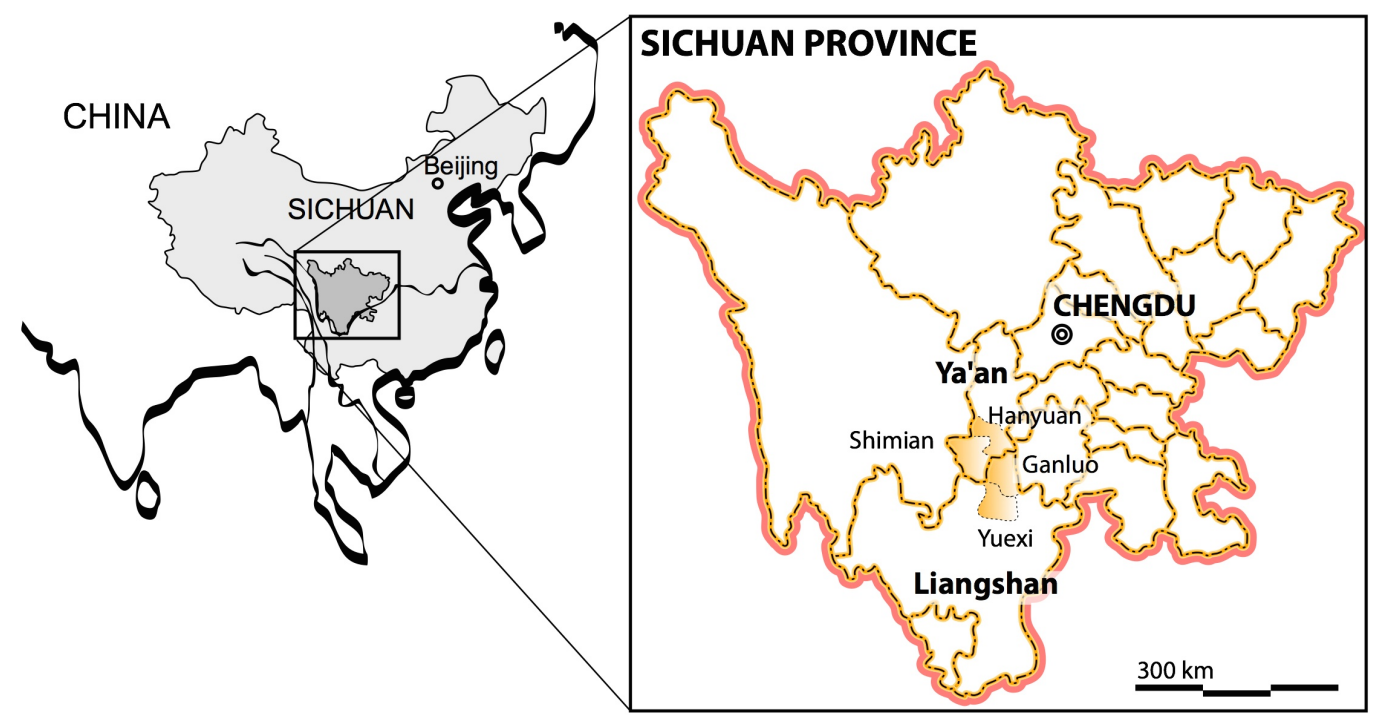

FIgURE 2. Distribution of the Ersu Language (adapted from Chirkova, Wang, Chen, Amelot, \& Kocjančič Antolík, 2015:188).

In all four counties, Ersu speakers are a minority and in contact with Nuosu and Mandarin, albeit to different extents. In the counties of Shimian and Hanyuan, Mandarin speakers form the ethnic majority, and the Ersu population is heavily Sinicized. Among the Ersu population in those two counties, reportedly only a few people are still proficient speakers of Ersu. In the counties of Ganluo and Yuexi, on the other hand, Nuosu speakers form the ethnic majority. In Yuexi in particular, Ersu settlements are interspersed with those of Nuosu, bringing them in close contact with the Nuosu language. Finally, Ganluo traditionally has the largest monolingual Ersuspeaking community (e.g., Munai, 2015:33). According to our Ganluo Ersu language consultants, "the Ersu people in Yuexi have a Nuosu accent; the Ersu people of Shimian have a Chinese accent. The Ersu as spoken in Zela and Liaoping townships [both in Ganluo county] is the purest form of Ersu" (78 year-old woman, illiterate, farmer).

Traditionally, the Ersu people have been farmers, practicing swidden agriculture - with a focus on cultivating buckwheat - as a major livelihood strategy 
(Schmitt, 2011, 2014). Before the 1980s, they followed a custom of marrying strictly within their own group. But starting with Deng Xiaoping's Reform and Opening-Up Policy (găigé kāifàng 改革开放) in the late 1970s following the Cultural Revolution (1966-1976), Ersu communities have been undergoing profound socioeconomic changes, as their region became more closely integrated into the Chinese state, as well as urbanization and environmental changes.

Integration with the national Chinese economy led to a shift from swiddening to cash crops (corn, potatoes, and soybeans). Implementation of the national reforestation program (tuigēng huánlín 退耕还林 or Returning Farmland to Forest Program) initiated in 1999 led to an occupational shift from agriculture to nonagricultural sectors. As a consequence, Ersu working-age people (both men and women) now commonly seek jobs in urban areas, and they spend most of the year outside of their home villages. Institutional reforms (including the reinstatement of China's national college entrance examinations (gāokăo 高考 in 1977) improved educational opportunities for young Ersu. The growing numbers of Ersu studying and working in urban areas also led to a change in marital practices. Intermarriages of Ersu people with Chinese and Nuosu are now very common.

The past decades have also witnessed important changes in the regional linguistic influences. Mandarin has firmly established itself as a regional dominant language and a local lingua franca, replacing Nuosu, the language of the local ethnic majority in that role. It is still possible to find older Ersu speakers (above sixty years of age) who are monolingual in Ersu, bilingual in Ersu and Nuosu, or trilingual in Ersu, Nuosu, and Mandarin; but most younger speakers (below thirty years of age) are bilingual in Ersu and Mandarin (Wu Da, 2004). 
Ersu is phonologically monosyllabic and tonal, with a simple binary contrast between $\mathrm{H}$ and $\mathrm{L}$ tones. All documented varieties (Chirkova et al., 2015; Liu, 1983 [2007]; Sun, 1982, 1983; Zhang, 2013) have relatively simple vowel inventories (consisting of six to eight oral vowels), and complex consonant systems (consisting of 36 to 39 simple consonants, and having a rich inventory of consonant clusters). Ersu is unwritten and not codified.

Ganluo Ersu appears to have the most complex consonant inventory of all Ersu varieties described to date. It has 39 simple consonant phonemes, a four-way contrast in affricates at the dental, alveolar, alveolopalatal and retroflex places of articulation (/ts $\mathrm{t} \int \mathrm{tr} \mathrm{t} 6 /$ ), and three types of clusters (prenasalized, clusters with a schwa-like segment, clusters with approximants). ${ }^{1}$ The canonical Ganluo Ersu syllable has the following linear structure: $\left(\mathrm{C}_{1}\right)\left(\mathrm{C}_{2}\right)\left(\mathrm{C}_{3}\right) \mathrm{V}$, where $\mathrm{C}_{1}$ can be nasal $(/ \mathrm{N} /)$ or a schwa-like segment (/ə/); $\mathrm{C}_{2}$ can be any consonant; $\mathrm{C}_{3}$ can be either $/ \mathrm{w} /$ or $/ \mathrm{j} / ; \mathrm{V}$ stands for vowel, and parentheses indicate optional constituents. Examples include /á/ 'I, first person singular pronoun', / $\mathrm{t}_{n}^{\mathrm{h} a ́} /$ 'millstone', $/ \mathrm{t}_{n}^{\mathrm{h}} \mathrm{wá} /$ 'mule', $/ \mathrm{Nt}_{n}^{\mathrm{h}} \mathrm{wá} /$ 'to be sharp'.

\section{Variation and variables}

One feature that distinguishes Ganluo Ersu from the Ersu varieties spoken in the remaining three counties, as well as from the neighbouring languages Nuosu ( $\mathrm{Li} \&$ Ma, 1983) and Mandarin (e.g., Sichuan sheng Ganluo xian difangzhi bianzuan weiyuanhui, 1996:591-596; Yuan, 2001:24-39), is the presence of typologically uncommon trilled retroflex sounds, namely trilled retroflex affricates $/ \mathrm{tr} t \mathrm{tr}^{\mathrm{h}} \mathrm{dr} /$ and the retroflex trill $/ \mathfrak{r} /$. These typologically uncommon trilled sounds are seen by Ersu speakers as the hallmark of the purest form of Ersu. Currently, they are subject to 
much variation across all age groups. In addition, we observe delateralization of the lateral fricative, devoicing of stops and affricates, and simplification of onsets. Notably, all of the variables involve phonological distinctions that are not present in Mandarin, the dominant contact language, hence suggesting a trend of phonological convergence between Ersu and Mandarin.

\section{Establishing change}

How do we know that Ganluo Ersu is experiencing contact-induced change due to Mandarin rather than other sources of change (cf. Poplack, Walker, \& Malcomson, 2006; Poplack, Zentz, \& Dion 2012; Torres Cacoullos \& Travis, 2010, 2015, 2016)? Paraphrasing Thomason (2001:93-4), Poplack and Levey (2010:410) stress that in order to determine whether contact-induced change is occurring, researchers need to (1) prove that the proposed interference features were not present in the pre-contact variety, (2) prove that the proposed interference features were present in the source variety prior to contact, and (3) rule out (or situate) internal motivations. These issues are addressed in turn below.

(1) The changes examined here have a relatively shallow time depth (from the late 1970s until present). The earlier attestations of Ganluo Ersu by Chinese linguists dating from the early 1980s (Liu, 1983; Sun, 1982, 1983) document a rich consonantal system with a voicing distinction in stops, affricates, and fricatives; a four-way contrast in affricates at the dental, alveolar, alveolopalatal and retroflex places of articulation; a rhotic trill; and various types of consonant clusters. In addition, those early Ersu reports are consistent with our apparent-time plots (discussed below), which provide strong evidence of the presence of all of the above 
features among the current older generations. Inasmuch as the Apparent Time Hypothesis can be assumed here as elsewhere (Labov, 1963), our apparent-time evidence points to a far less "Chinese-like" phonology in prior generations of Ganluo Ersu, matching Sun (1982, 1983) and Liu's (1983) earlier Ersu work.

(2) The phonological history of the source variety, Mandarin Chinese, is well researched and understood. Southwestern Mandarin, the Chinese variety in contact with Ersu, is a subgroup of Mandarin Chinese dialects spoken by over $70 \%$ of China's Han population. Brought to Southwestern China in the Ming (1368-1644) and Qing (1644-1911) dynasties, it is the most homogeneous of all Mandarin groups. It is also closely related to the standard language of China (Standard Chinese or Putonghua), which is based on a northern Mandarin dialect. The distinctive phonological characteristics of Mandarin dialects include (Norman, 1999:190-197, Yuan et al., 2001:24-39):

(i) The Middle Chinese ${ }^{2}$ voiced obstruents (stops, affricates and fricatives) all became devoiced in Mandarin, hence eliminating voicing as a distinctive feature in the phonological system of these dialects.

(ii) Most Mandarin dialects have a three-way contrast in affricates at the dental (or alveolar), post-alveolar (or retroflex), and palatal places of articulation (/ts, t $\int$ or ts, t6/) (e.g., Yuan, 2001:25, Table 2). However, some Southwestern Mandarin dialects, including Ganluo Mandarin, do not have a series of retroflex affricates and sibilants distinct from a plain dental (or alveolar) series (ibid., Sichuan sheng Ganluo xian difangzhi bianzuan weiyuanhui, 1996:591595). We also note that Mandarin retroflexes (as in Standard Mandarin) are articulatorilly quite distinct from Ersu retroflexes, being rather laminal or 


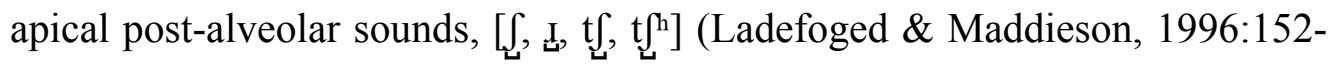
153, Lee \& Zee, 2003:110).

(iii-iv) Mandarin dialects do not have a voiceless lateral fricative (/1/) or consonant clusters.

(3) Regarding possible internal changes, our data yield no evidence that any of the four variables are sensitive to phonetic conditioning factors that could affect the probability of their occurrence. Put differently, the observed changes occur generally and are not dependent on the phonetic context. Notably, the examined changes do not merely produce novel allophones of existing phonemes, but rather they involve deletion of phonemes in the phonemic inventory of Ersu. Specifically, the changes result in merger of voiced and voiceless stops, and the elimination of retroflex sounds, / $1 /$, and consonant clusters. That is, they lead to a loss of phonemic oppositions, thereby changing the structural organization of the inventory of Ersu sounds. Moreover, these structural changes are all clearly moving in the same direction: toward a consonantal system that is more in line with Mandarin phonology. With these lines of evidence, and following Occam's Razor, we conclude that Mandarin-induced phonological change is occurring in Ganluo Ersu.

Finally, we also note that comparable processes of Chinese-influenced phonological change have been reported in other small minority languages of western and southwestern China (e.g., Chirkova, 2014; Gao, 2017; Jamsu Reynolds, 2012; Li \& Li, 2015; Zhou, 2012).

\section{MeTHODS}

Our "triangular" collaboration 
We have developed a "triangular" collaborative research approach involving three coauthors: (a) a documentary and descriptive linguist, (b) a variationist sociolinguist, and (c) a native Ersu linguist and ethnographer who is a member of the Ganluo Ersu community. With this triangular approach, we are able to thoroughly examine emic and etic perspectives on the language and culture along with quantitative analyses. Such a multifaceted team is especially valuable in lesser-studied languages like Ganluo Ersu where prior literature is limited.

\section{Data collection}

Data reported in this study were collected in two field trips to Ganluo County in February and August of 2015, with speakers from all Ersu-speaking townships and villages. ${ }^{3}$ The data were collected by Wang Dehe, a native speaker of Ersu and coauthor of the present study. Born and raised in Ganluo county (Zela Township), Wang is an Ersu linguist, ethnographer, and historian, who is actively engaged in the documentation and research of the Ersu language. The bulk of the data were collected by Wang in February 2015 during Chinese New Year Celebrations. That time period was chosen because of the long-held tradition among the Ersu to return home and reunite with their family during Chinese New Year.

Participants were recruited through family and friends. They were informed of the general purpose of the research project-documentation of the Ersu languagebut not given any information about the linguistic features chosen for this study, so as not to influence their recordings. Participants were recruited randomly based on their availability, except for the second field trip where male speakers were prioritized to help balance the data set for gender. 
All recording sessions consisted of two parts. In the first part, interviewees were asked to read in Ersu the list of 116 words written in Chinese characters (henceforth: Word List). The Word List includes 37 syllables with retroflex sounds as well as words with various other consonantal variation, and also "distractor" words that do not contain any known variation (see Appendix). In all words, consonants are in syllable-onset position. Literate speakers (the majority) read the list directly from the page. Illiterate speakers with limited knowledge of Chinese (a small group of elderly speakers, mostly women) were prompted by Wang. He read the list in Ersu, placing each word in a minimal context. For example: /rájí támá, rá/ “[say] 'chicken’ as in 'chicken and hen"”; /vé ozú rá əzú, ozú/ "[say] 'raise' as in 'raise pigs and chicken"”; /gámé dèdrù, drú/ "[say] 'dry' as in 'the clothes are dry"”. The interviewees were asked to pronounce each word in the list three times.

In the second part of the interview (henceforth: Q\&A), participants were asked to provide personal information (name, age, place of birth and residence, education, occupation), and respond to ethnographic questions. In order to facilitate the transcription of data by Mandarin-speaking research assistants, the Q\&A interview was, whenever possible, in Mandarin. As a result, 48 interviews were conducted in Chinese, and 49 in Ersu. The ethnographic questions are listed below.

(1) Which variety of Ersu do they consider as standard or prestigious? (Given that the notions of "prestige" and "standard" Ersu are generally unknown to Ersu speakers, these notions were translated as "pleasing to the ear", 好听 in Mandarin, /bàní jàdzźń/ in Ersu.)

(2) Is the Ersu variety of your home village different from that of the neighboring villages? Is the Ersu as spoken in the neighboring villages pleasing to the ear? Why? 
(3) Do you think Ersu is changing? Are there any differences in the Ersu as spoken by older, middle-aged, young people and children? Are there any differences between the Ersu as spoken by men and women?

Interviews took between twelve to twenty minutes each. All interviews were recorded in uncompressed Waveform Audio File Format (.wav) using a Fostex FR digital audio recorder and a Beyerdynamic M88 N microphone. All recordings are mono (16-bit at $48 \mathrm{kHz})$. The present discussion is based on auditory analysis. All sound files, textgrids, transcriptions, and metadata related to this study are made available at the Endangered Languages Archive (ELAR). ${ }^{4}$

Figure 3 shows the age and sex distribution of the speakers in our study. Most speakers were born and raised in Ersu-speaking villages in Ganluo County. Four speakers were born outside Ganluo (three speakers, two female and one male, were born in Yuexi County; and one speaker, male, was born in Shimian County), but they spent most of their lives in Ganluo County.
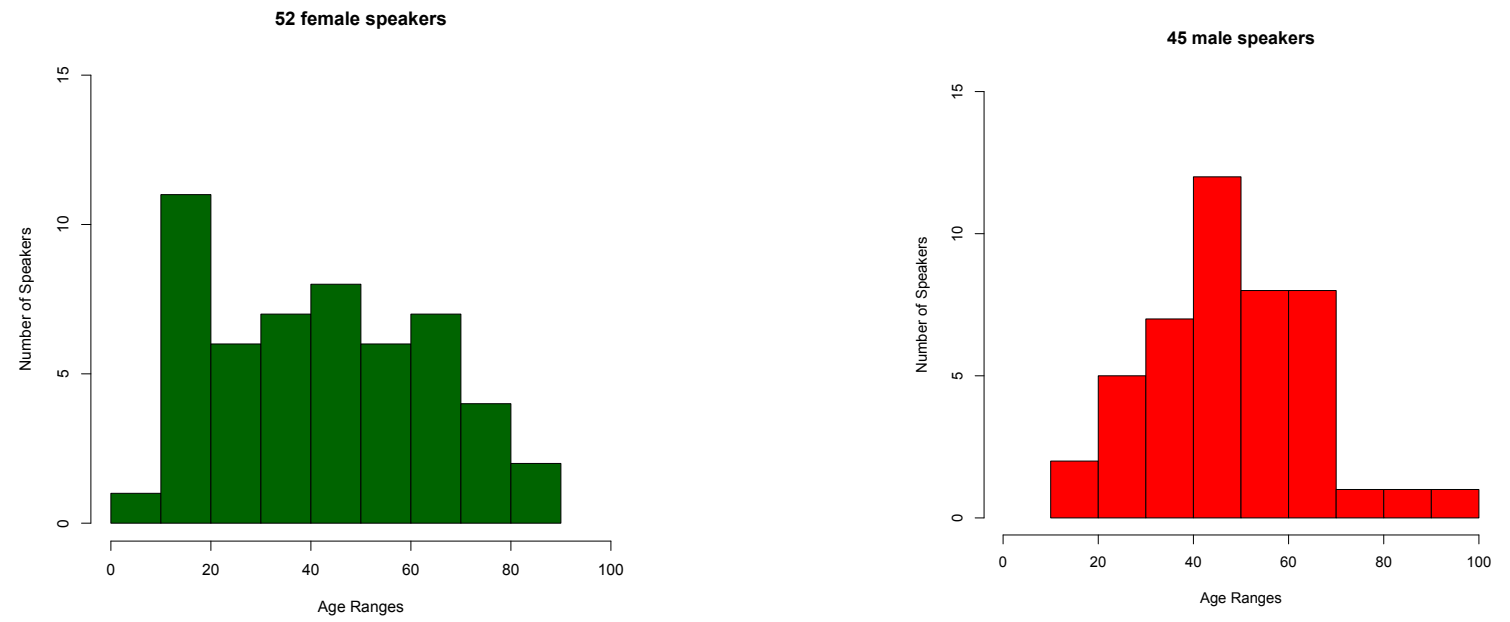

FIGURE 3. Histograms of speaker age, organized by sex.

We must note some methodological limitations of our study. First, we recognize that the use of word list data lacks the naturalness of spontaneous speech. 
However, a word list makes it possible to collect comparable data from a large and diverse set of speakers in a short time. This was crucial for our project since we needed a large sample across the population that would represent diversity in gender, age, education, and occupation. With limited field resources in this project, we prioritized this approach rather than longer interviews or conversational recordings, which would require further resources for transcription.

An additional problem is that for illiterate speakers the word list was read by the co-author Wang Dehe, hence opening up the possibility that his speech may have influence on the production of the interviewee. To examine this possibility, we conducted analysis of available spontaneous Ersu speech samples, that is, all 49 available Q\&A interviews in Ersu, which also include all interviews with illiterate speakers. ${ }^{5}$ Specifically, we made auditory counts of the four variables in spontaneous speech and compared the resulting patterns for consistency in the use of the four variables by the same speaker in word list elicitation. Our preliminary analysis did not detect any discrepancy in the use of the four variables in these two contexts. ${ }^{6}$

We acknowledge the constraints that the nature of the data places on the interpretation of the study's results. For a lesser-studied language community, sometimes it is necessary to start with a basic variationist description before moving on to other aspects of sociolinguistic research (Meyerhoff \& Stanford, 2015:10-11).

\section{Data analysis: Social and linguistic factors}

Social factors considered for our analysis include age, sex, education, and occupation. We recognize that these factors should be considered from an emic point of view, and our analysis strives for a culturally sensitive and locally relevant approach, rather than trying to artificially force the Ersu data into Western categories (cf. Eckert, 1997; 
Guy, 1988; Rickford, 1986). Johnstone wisely reminds us to consider the "local knowledge that motivates and explains the behavior of a particular group" (2004:76). At the same time, we are aiming for quantifiable results that can be compared crosslinguistically. We believe that our triangular research approach helps us to maintain the appropriate balance in this respect. First, for age, sex and education, we use simple categories $(\mathrm{M} / \mathrm{F})$ and continuous scales for age and education. Though simplistic, we believe this approach is an appropriate, practical way to make progress in this study as the first quantitative exploration of Ersu. Future research can take further steps to problematize these categories, find more nuanced gendered speaking styles, or probe deeper emic experiences of age, and so on (see, e.g., Eckert, 2012; Eckert \& McConnell-Ginet, 1992; Levon, 2015, inter alia).

For occupation, as discussed below, our Ersu co-author (Wang) developed an emic, locally appropriate scale that is reminiscent of occupational scales in prior variationist work but adjusted to match the Ersu experience. Traditionally, Ersu communities revolved around small-scale agricultural work in relatively egalitarian villages organized by kinship (Sichuan sheng Ganluo xian difangzhi bianzuan weiyuanhui, 1996:567). Naturally, during that earlier era, an occupational scale (Western or otherwise) would have been largely meaningless since almost everyone in a village was a subsistence farmer (see Introduction). However, our study examines Ersu during the current period of intense contact with Chinese.

Education. We now describe each of the social factors in more detail. We use a 1-6 scale for education, following scales in Labov (2001, cited in Ash, 2013:355), but we adapt it for the Ganluo Ersu setting in China. Our scale is shown in Table 1. 
TABLE 1. The 1-6 Educational Scale

\begin{tabular}{|l|l|l|}
\hline Level & Years & Description \\
\hline 6 & 4 & University degree (Bachelor's Degree, xueshi xuewei 学士学位) \\
\hline 5 & 3 & \begin{tabular}{l} 
Senior technical degree (dazhuan 大专) \\
\hline 4
\end{tabular} \\
\hline 3 & 3 & $\begin{array}{l}\text { Upper secondary school (gaozhong 高中) / Secondary technical } \\
\text { degree (zhongzhuan 中专) }\end{array}$ \\
\hline 2 & 3 & Junior (lower) secondary school (chuzhong 初中) \\
\hline 1 & 3 & Upper primary school (gaoxiao 高校) \\
\hline
\end{tabular}

The speakers in our study range from illiterate ( 0 years) to a Bachelor's degree (16 years). We include 2 more years on the scale (maximum 18 years) for future comparison since some locals have achieved a Master's degree (shuoshi xuewei 硕士 学位), though not among our study participants. This scale captures the overall gradient of community education based on the interviewees' descriptions of their educational backgrounds and diplomas, although we note that there is some variability in the precise number of years constituting different diplomas at different points in PRC's history. Lastly, note that in Ganluo and many other minority communities in China, the local education system provides exposure to Mandarin, so our factor of education may be viewed as a proxy for Mandarin exposure to some extent.

Occupation. Speakers' occupations were divided by co-author Wang Dehe into six categories reflecting the local social and cultural context in which the Ersu speakers live. Dodsworth (2011) discusses the importance of "locally meaningful distinctions in socioeconomic (or other types of) status that vary by region and community" (198).

Sociolinguists have utilized a number of occupational scales for work in Western industrialized communities (Ash, 2013), as well as identity-based approaches that avoid socioeconomic categories (for a review, see Dodsworth [2011]). While quantified scales can uncover important broad-range perspectives, any quantified 
scale or set of categories runs the risk of "essentializing" and over-simplifying the results. For this reason, some scholars focus on the micro-level of individual style shifts and dynamic, interactive, intersectional constructions of identity (e.g., Eckert, 2001, 2012). Such approaches all provide valuable insights, especially when there is already a great deal of background information and prior sociolinguistic data available. But sometimes the prior sociolinguistic data is not available, as in the case of Ganluo Ersu, and so we need to start at a more basic level.

Table 2 compares Labov's (2001) and Wang Dehe's scales for Ganluo Ersu. Despite the differences in specific categories, we note that the notion of categories and stratification is shared in both locations. We also recall that scholars often point out the danger of "exoticizing" other societies to the point that they almost seem to have nothing in common with our own (Gilroy, 1995:11-12; Groves, 2003; Hopper, 2007:38). That is, Ganluo and New York City are far apart in many ways, but perhaps not in other ways. Education and occupation are typically correlated to some extent, so we need to examine their relationship closely in Ersu. In the following analyses, we consider interactions and correlations in these factors.

TABLE 2. Occupational scales

\begin{tabular}{|l|l|l|}
\hline & Labov (2001:61) & Wang Dehe's scale for Ganluo \\
\hline 6 & Professional, owner-director of large firm & High school teachers and university professors \\
\hline 5 & White collar: proprietor, manager & Local officials (township and village level) \\
\hline 4 & White collar: merchant, foreman, sales & Doctors \\
\hline 3 & Blue collar: skilled & Elementary and middle school teachers \\
\hline 2 & Blue collar: unskilled & Small retailers \\
\hline 1 & Unemployed & Farmers and migrant workers \\
\hline
\end{tabular}

\section{Combined index of education and occupation}

Labov (2001:185-6) creates a combined index defined as education + occupation + house value (cited in Dodsworth, 2011:193). He finds that the combined index performs better in multiple regressions than the individual factors (education, 
occupation, house value), and so he bases his primary analyses on the combined index. Since our study probes into the applicability of Labovian methods to a lesserstudied language (see introduction), we take this combinatorial approach as well. Following Labov, we created a Combined Index as our primary measure of socioeconomic status (SES), and we defined it as education + occupation. Since both education and occupation are 1-6 scales, the Combined Index scale ranges from 2-12. As for the house value factor in Labov's index, this factor is not available in our dataset and may not translate reliably into a rural China environment.

We find that this Combined Index is helpful in reflecting the significant socioeconomic changes affecting rural China. As Figure 4 shows, there is a strong correlation between education and occupation, as expected since education affects a person's occupational prospects almost anywhere in the world. However, there is still a good amount of variance, so our Combined Index helps to ensure that a given speaker's SES is not dependent solely on education or solely on occupation, as this could skew the results.

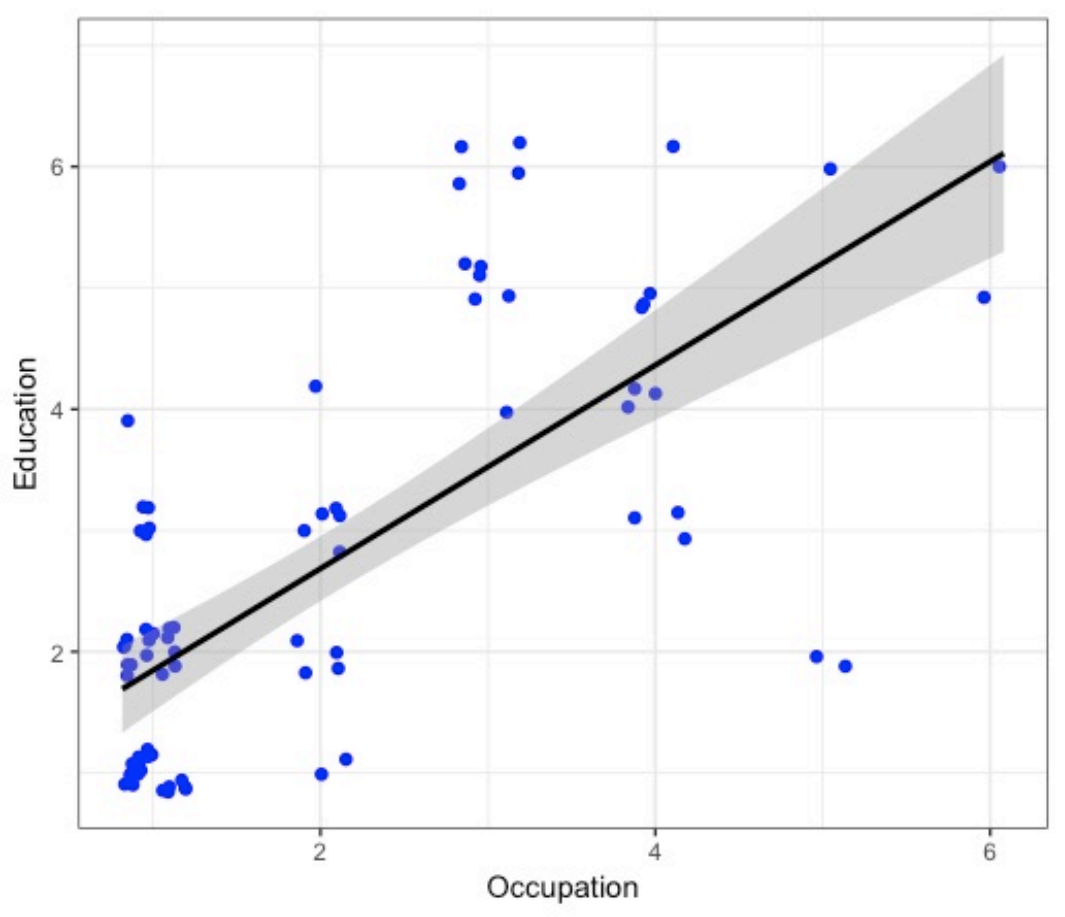


FIGURE 4. Correlation of Education and Occupation for adult speakers. $\mathrm{R}^{2}=0.502$, $p<0.0001$. Jitter added so that individual speakers are visible.

\section{Functional domains of language use and language choice}

In a multilingual speech community like Ganluo Ersu, different languages have distinct functional and contextual allocations. As typical for a society with a dominant majority language and a minority language, the minority language is mostly used within the community, inside the family, and in informal contexts. The majority language, by contrast, is used in communication with the outside world, outside family, and in public domains (King, 1989:140, Tsunoda, 2006:65-69). As is typical in language endangerment situations marked by competition of the minority and majority languages for functional domains of use (e.g., King, 1989), the minority language in the Ganluo Ersu community is restricted to a limited set of domains. The majority language, on the other hand, dominates the education system and work in public domains and it is consciously or unconsciously associated for Ersu speakers with high social status and opportunities for socio-economic advancement. ${ }^{7}$

This functional differentiation between the minority and majority languages closely correlates with the occupation scale devised by Wang Dehe. Overall, the functional domains occupied by Ersu diminish as we move up the occupation scale in Table 3, while the functional domains occupied by Mandarin increase conversely. The languages in the Language Choice column are listed according to authors' qualitative observations of the Ganluo Ersu community. In addition, Munai (2015) provides a detailed investigation of the various functional domains of use of Ersu, Nuosu, and Mandarin in Ganluo County.

TABLE 3. Functional domains and language choice versus occupation

\begin{tabular}{|l|l|l|l|}
\hline & Occupational scale for Ganluo & Functional domain & Language choice \\
\hline 6 & $\begin{array}{l}\text { High school teachers and } \\
\text { university professors }\end{array}$ & $\begin{array}{l}\text { Outside the community, } \\
\text { national, public domains }\end{array}$ & Mandarin \\
\hline
\end{tabular}




\begin{tabular}{|c|l|l|l|}
\hline 5 & $\begin{array}{l}\text { Local officials (township and } \\
\text { village level) }\end{array}$ & $\begin{array}{l}\text { Outside the community, } \\
\text { regional, public domains }\end{array}$ & Mandarin \\
\hline 4 & Doctors & $\begin{array}{l}\text { Within the community and } \\
\text { with the outside world, } \\
\text { public domains }\end{array}$ & Mandarin \\
\hline 3 & $\begin{array}{l}\text { Elementary and middle school } \\
\text { teachers }\end{array}$ & $\begin{array}{l}\text { Within the community and } \\
\text { with the outside world }\end{array}$ & Mandarin, some Ersu \\
\hline 2 & Small retailers & Within the community & Ersu, Mandarin \\
\hline 1 & Farmers and migrant workers & $\begin{array}{l}\text { Mostly within the } \\
\text { community }\end{array}$ & $\begin{array}{l}\text { Ersu (at home) (Mandarin } \\
\text { for migrant workers when } \\
\text { in Chinese regions) }\end{array}$ \\
\hline
\end{tabular}

In contrast to Mandarin, which is the dominant contact language for the Ersu, the role of Nuosu is more sporadic and varies according to specific social circumstances. For example, an Ersu-speaker may have a Nuosu co-worker, spouse, friend, or neighbor (Munai, 2015:58-59).

\section{RESULTS}

We first discuss the loss of retroflex segments separately (next section) from the other variables since the retroflex analysis involves our largest dataset and a number of complex socioeconomic issues.

\section{Loss of retroflexes}

The first variable we analyze is the presence or absence of retroflex segments: trilled retroflex affricates $/ \mathrm{tr} \mathrm{tr}^{\mathrm{h}} \mathrm{dr} /$ and the rhotic trill / $\mathrm{r} /$ (Table 4). These retroflex segments are typically produced with the underside of the tongue top approaching or having contact with the hard palate. They may or may not have a trill release (that is, $/ \mathrm{tr}_{\mathrm{t}} \mathrm{t}^{\mathrm{h}}$ $\mathrm{dr} /$ or $/ \mathrm{ts} \mathrm{ts}^{\mathrm{h}} \mathrm{dz} / ; / \mathrm{r} /$ or $\left./ \mathrm{r} /\right)$ (see Chirkova et al., 2015; Liu, 1983; Sun, 1982, 1983).

In our data, the release of the retroflex affricates may be realized variably as $/ \mathrm{r} /, / \mathrm{J} /$ and $/ \mathrm{x} /$. Using our Word List data, we auditorily analyzed each word where a retroflex is present in conservative forms of Ersu, such as /trá/ or /ţá/ 'star'. In our 
word list data, there is an average of 128 such instances per speaker, for a total of 12,501 tokens $(10,830$ for the adult-only dataset).

TABLE 4. Examples of words with retroflexes in conservative Ganluo Ersu pronunciation

\begin{tabular}{|c|c|}
\hline /trá/ or /tsáá/ 'line (e.g., of characters)' & /tró/ or /tşá/ 'star' \\
\hline$/$ trú/ or /tsú/ 'sweat' & $/ \mathrm{tr}^{\mathrm{h}} \mathrm{o} /$ or $/ \mathrm{ts}^{\mathrm{h}} \mathrm{o} /$ 'dog' \\
\hline 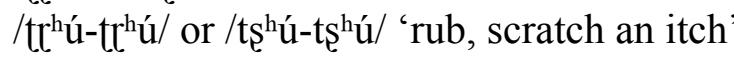 & /drà/ or /dzàa 'drop, fall' \\
\hline /drò/ or /dzò / 'pot, pan' & /drú/ or /dzú/ 'be dry' \\
\hline /rá/ or /rá/ 'chicken' & /ró/ or /ró/ 'bone' \\
\hline / $\mathrm{e} \varepsilon$ / or /ré/ 'land, non-irrigated farmland' & $/$ rú/ or /rú/ 'shave' \\
\hline
\end{tabular}

Age and sex

Figure 5 shows the percent realized as retroflexes as a function of speaker age and sex. Female speakers are represented by black dots, and male speakers as gray triangles.

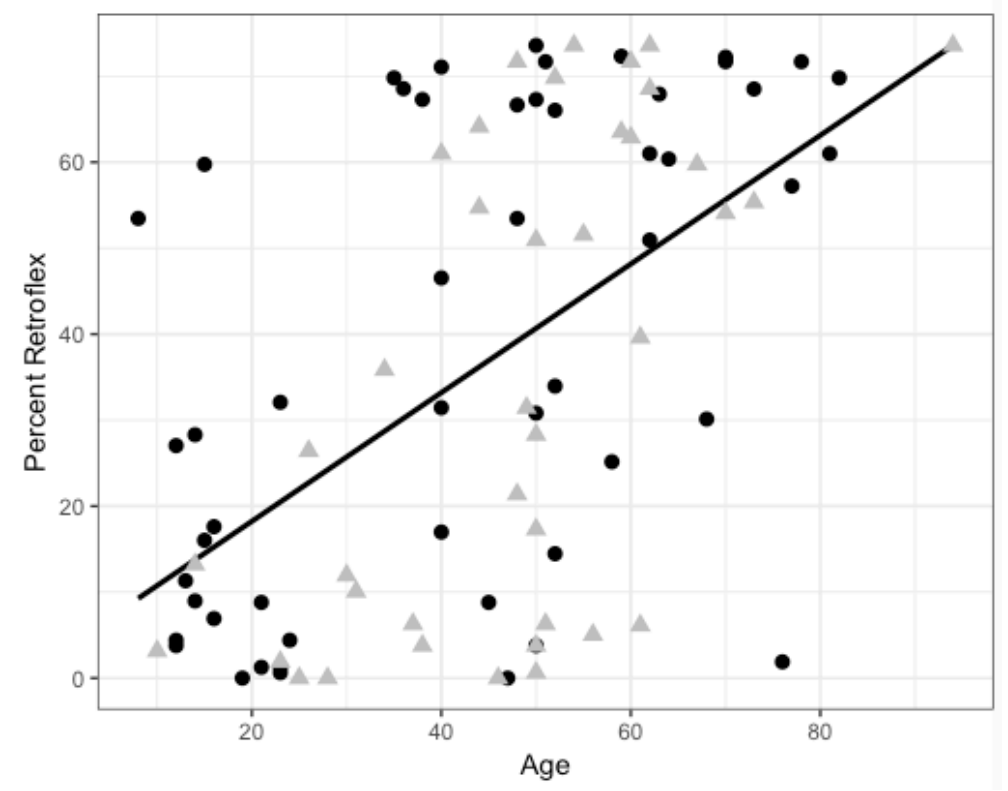

FIGURE 5. Percent of retroflexes in syllables that may contain a retroflex, as a function of speaker age. Female=black dots. Male=gray triangles. Regression on percent retroflex versus age: $0.748 \%$ higher per year older, $\mathrm{R}^{2}=0.296, p<0.0001$. All speakers, including children.

In Figure 5, first note that there is a clear pattern of decreasing retroflexes in apparent time. Secondly, we note that the greatest variance is found in the middle-aged 
speakers (e.g., age 50), which is understandable as those speakers are in the middle generation between the two ends of the sound change: older speakers are more likely to have the conservative (retroflex) pronunciation, while younger speakers are more likely to have non-retroflex pronunciations, with some exceptions as seen in the plot.

The role of socioeconomic status can be seen in Figure 6, which is a plot of retroflexes as a function of SES (Combined Index). Notice the large group of people with in the upper-left corner (marked with an ellipse). These people have SES levels around 2-3, that is, farmers and other low-education, low-status people. The speakers in this group have high percentages of retroflexes. (Note: Jitter has been added to the plot to help distinguish individuals.)

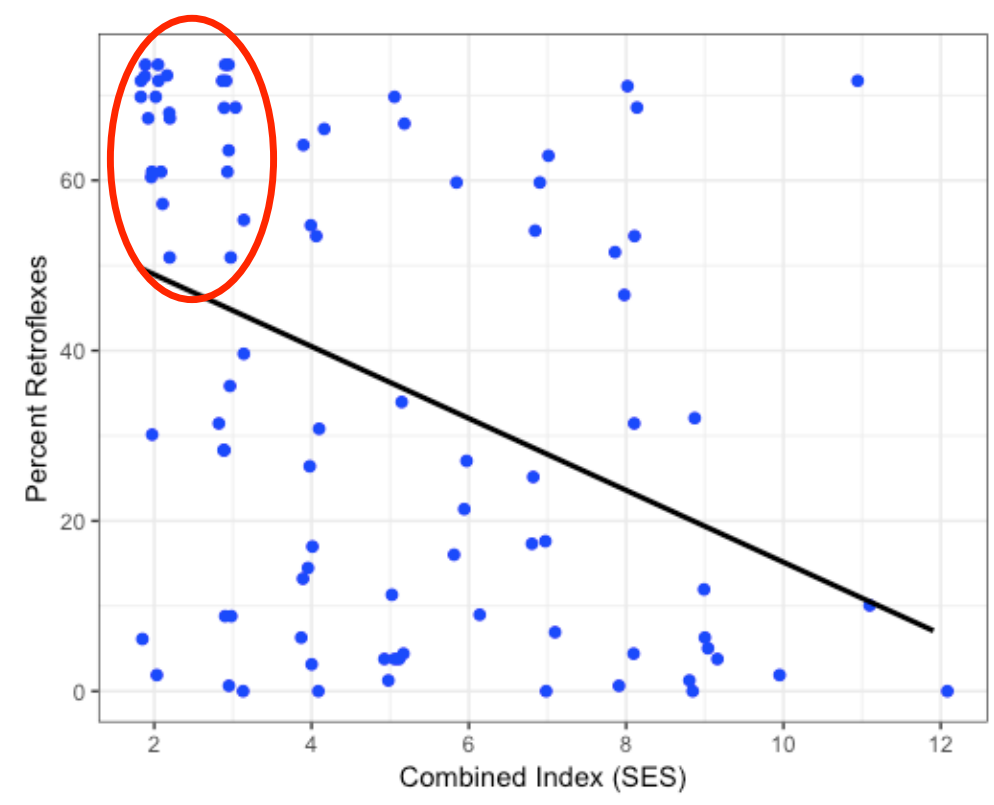

FIgURE 6. Percent of retroflexes as a function of Combined Index (SES), $p=0.004$, $6.5 \%$ lower percentage of retroflexes for each step higher on the occupation scale. $\mathrm{R}^{2}=0.104$. Adult speakers. The ellipse highlights farmers and others with low SES who have high percentages of retroflexes. Jitter added.

\section{Multivariate analysis of retroflexes}

We now run a multivariate logistic regression in Rbrul (Johnson, 2009) to model the data as a function of age, sex, and SES, with speaker and following vowel as random effects. The following vowel is included to examine possible phonetic factors that 
could condition the realization of retroflexes. For the multivariate analysis, we ran logistic regression models in Rbrul and selected the best-fit model. There are 13 children in the data set, and their educational and occupational factors need to be handled thoughtfully in the analyses. For statistical analyses involving occupation and education, we removed the children. For statistical analyses involving just age and sex, we included the children. Here is our reasoning for this bifurcated analysis: In the rapidly changing socioeconomic environment of contemporary rural China, it is not possible to estimate a child's social status from the parents' education and occupation; many families are rapidly undergoing upward mobility across generations, and so parents' occupation/education is not an accurate predictor of a child's socioeconomic identity or trajectory. Children are also frequently raised by different family members for certain periods of time when parents leave the home for migrant labor. Moreover, a given child's academic prospects, scores, and occupational trajectory are unknown, so it may be inappropriate to directly compare a child who is currently in 6th grade with a middle-aged farmer who left school in 6th grade many years ago, for example. Future studies could probe for more detailed information about children's personal socioeconomic/educational plans and identities, and also collect details about caregivers.

Tables 5 show our results for retroflexes. The best-fit model without children shows age and SES as significant. For each year older, there is a $0.52 \%$ increase in odds of producing a retroflex in words that contain retroflexes in conservative speech. As for SES, the model shows that for each step higher on the 2-12 Combined Index SES scale, there is a $15 \%$ decrease in odds of producing a retroflex. Sex is not significant, nor are any interactions. Note: Two young adults (aged 19 and 21) were current students in a vocational school (dazhuan 大专), a career path which 
corresponds most closely to level 3 on our occupational scale.

Finally, the best-fit model when children are included shows age as significant, with a $4.8 \%$ increase in odds of producing a retroflex for each year older.

TABLE 5. Retroflexes by age, logistic regression results, best-fit model (Rbrul;

Johnson, 2009)

\begin{tabular}{|c|c|}
\hline \multicolumn{2}{|r|}{ Not including children } \\
\hline Factors & Log-odds \\
\hline $\mathrm{Age}^{* * *} p<0.0001$ & $\begin{array}{l}0.051 \text {, that is } 0.52 \% \text { higher odds of retroflex per year } \\
\text { older }\end{array}$ \\
\hline $\begin{array}{l}\text { SES* (Combined Index }) \\
p=0.0317\end{array}$ & $\begin{array}{l}-0.165, \text { that is } 15 \% \text { decrease in odds of retroflex for } \\
\text { each step higher on the } 1-6 \text { Combined Index SES } \\
\text { scale }\end{array}$ \\
\hline Sex and Interactions & n.s \\
\hline \multicolumn{2}{|c|}{$\begin{array}{l}\mathrm{R}^{2} \text { fixed }=0.17, \mathrm{R}^{2} \text { random }=0.39, \mathrm{~N}=13,341 \text { tokens, } 84 \text { adult speakers } \\
\text { log-likelihood }-6586.6 \mathrm{Random} \text { : Speaker, Following Vowel }\end{array}$} \\
\hline \multicolumn{2}{|r|}{ Including children } \\
\hline Factors & Log-odds \\
\hline $\operatorname{Age}^{* * *}(p<0.0001)$ & $\begin{array}{l}0.047 \text {, that is } 4.8 \% \text { higher odds of retroflex per year } \\
\text { older }\end{array}$ \\
\hline Sex & n.s \\
\hline $\begin{array}{l}\mathrm{R}^{2} \text { fixed }=0.126, \mathrm{R}^{2} \text { ran } \\
\text { log-likelihood }-7456.1\end{array}$ & $\begin{array}{l}\mathrm{N}=15,402 \text { tokens, } 97 \text { speakers } \\
\text { eaker, Following vowel }\end{array}$ \\
\hline
\end{tabular}

Figure 7 provides a view of age and percent retroflex in terms of SES levels. To help visualize the results, in this figure the Combined Index is divided into three categories: low (black dots), medium (gray dots), and high (white dots). As explained above, it is necessary to exclude children in Figure 7 and other SES analyses. Comparing the lower left corner with the rest of the plot, we can see the general tendency for higher SES speakers to be younger speakers who produce few retroflexes (lower left corner). 


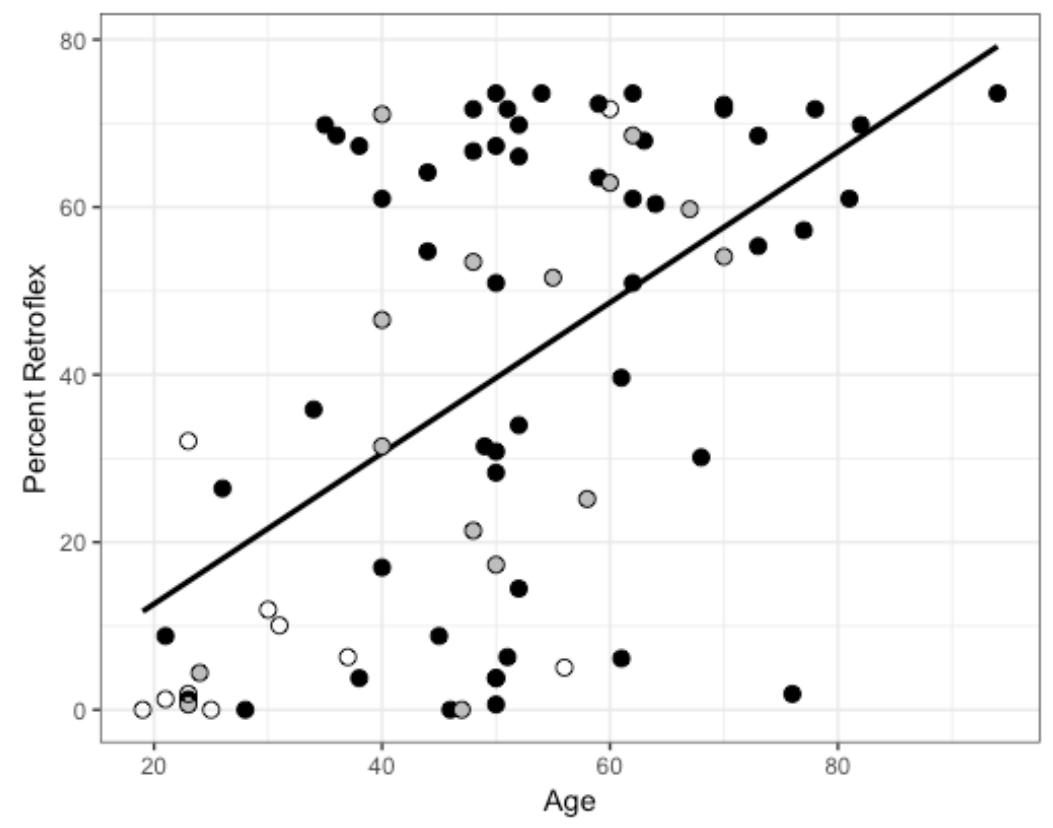

FIGURE 7. Percent retroflex in terms of Age and SES (Combined Index). Black dots=low SES level, Gray dots = medium SES level, White dots = high SES level. Adult speakers only.

\section{Sex interactions}

Now that we have established a basic analysis for retroflexes, we would like to probe more deeply into sex as a factor. As discussed below, there are more women than men on the lowest parts of our Combined Index SES scale, but this is changing rapidly in apparent time. We would like to see in what ways this social change may correlate with retroflex pronunciation. In the broad-based modeling above, sex did not emerge as significant, but we have a number of empirical and sociocultural reasons to suspect that it could be playing a role. We therefore turn to a more fine-grained analysis.

First, consider Figure 8, which plots SES in terms of age and sex. Notice the preponderance of women (black dots) in the lowest SES level, while there are more men in higher SES levels than women across most age categories. Next, observe the different slopes of the gendered trend lines. 


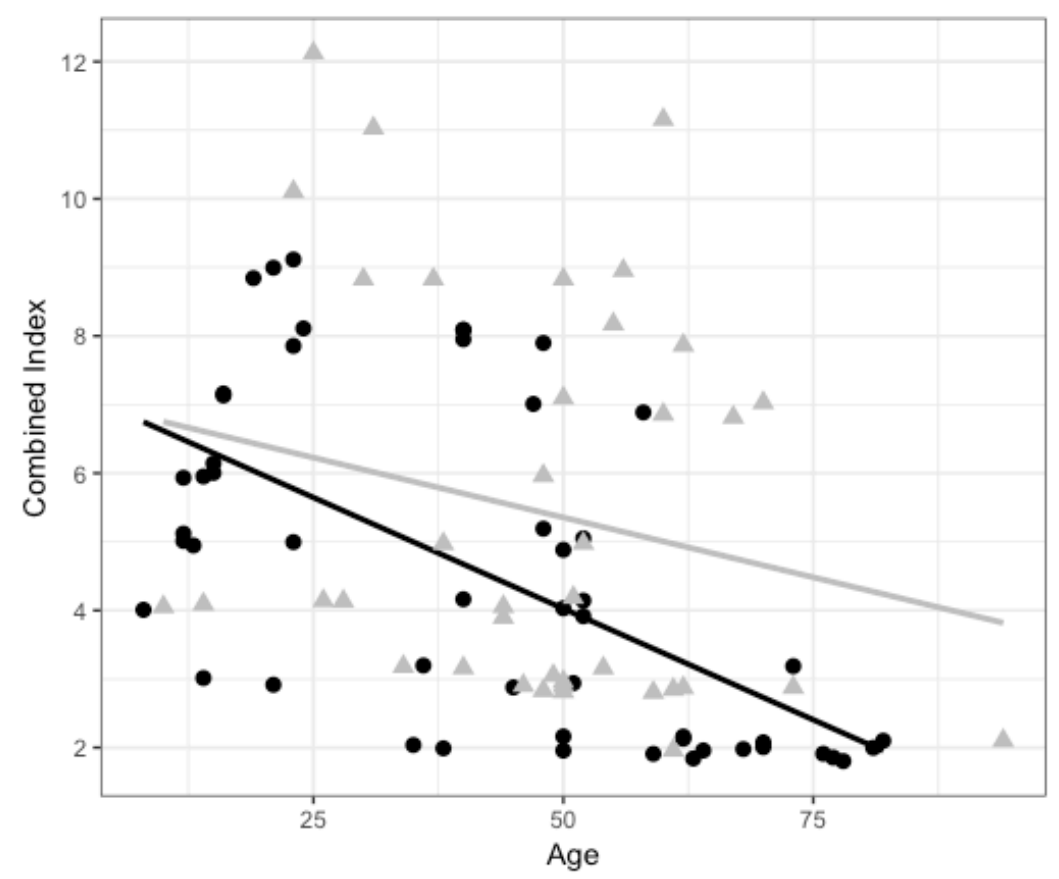

FIgURE 8. Age versus SES (Combined Index). Black dots $=$ women, gray triangles $=$ men. For women: -0.064 SES steps per year older, $\mathrm{R}^{2}=0.35, p<0.0001$. For men: 0.035 SES steps per year older, $\mathrm{R}^{2}=0.04$, n.s., $p=0.2099$. Jitter added.

The contrast in slopes suggests that Ersu women's socioeconomic status is changing in apparent time more quickly than men's. In fact, for the men, there is no significant change in SES across apparent time $\left(p=0.2099, \mathrm{R}^{2}=0.04\right)$, whereas for the women there is a significant change $\left(p<0.0001, \mathrm{R}^{2}=0.35\right)$. Most of the older women are found in the low SES levels, unlike the men. In particular, notice the large number of older women with low SES levels compared to the group of young women at higher levels 5-9. This sharp generational change reflects the fact that in the past women had far fewer educational opportunities and chances for occupational advancement. In recent decades, China's socioeconomic changes have affected the whole population. Yet it is the women who have experienced the most profound changes in lifestyle - because they were farther behind - hence the sharply increasing slope for women in Figure 8. These patterns are sociologically interesting in the context of the rapidly changing 
economy of China. Naturally, they are also interesting for sociolinguistics, as language reflects and constructs society (Bucholtz, 1999:209; Coupland, 2001:198-9).

Such gendered contrasts across age and socioeconomic status emerge in our analysis of retroflexes. When we examine retroflexes as a function of SES, there is a clear contrast in sex. In the upper-left corner of Figure 9, notice the large group of low-SES women (black dots) who have high retroflex percentages. For the linear regressions (trend lines) of Figure 9, SES is a significant factor for women's use of retroflexes $\left(\mathrm{R}^{2}=0.288, p<0.0001\right)$ but not for men $\left(\mathrm{R}^{2}=0.061, p=0.129\right)$. That is, women's percentage of retroflexes decreases dramatically as socioeconomic status increases, whereas men are more stable for this factor. Gendered Rbrul logistic regressions on presence/absence of retroflexes support this analysis. As Table 6 shows, women's percentage of retroflexes is best predicted by SES and not by age, while men's percentage of retroflexes is best predicted by age and not by SES.

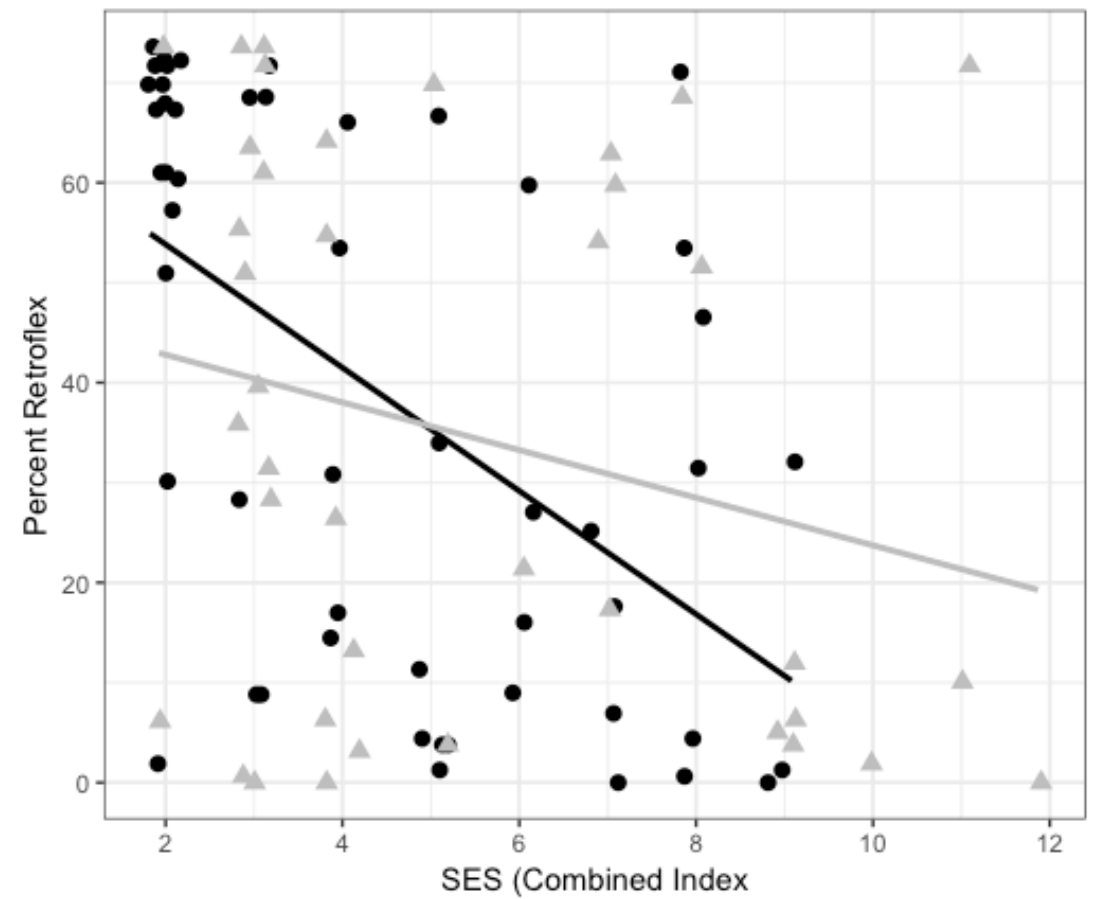

FIGURE 9. Percent retroflex as a function of SES for the 84 adult speakers. Black dots $=$ women, $\mathrm{R}^{2}=0.368, p<0.0001$. Gray triangles $=$ men, $\mathrm{R}^{2}=0.059$, n.s. $(p=0.117)$. Jitter added. 
TABLE 6. Retroflexes by sex, logistic regression results (best-fit model), not including children

\begin{tabular}{|c|c|}
\hline \multicolumn{2}{|r|}{ Women only } \\
\hline Factors & Log-odds \\
\hline $\begin{array}{l}\text { Combined Index } * * * \\
(p=0.0002)\end{array}$ & $\begin{array}{l}-0.435 \text {, that is, } 35.2 \% \text { lower odds of retroflex per step higher on } \\
\text { the } 2-12 \text { SES scale }\end{array}$ \\
\hline Age n.s. & ( \\
\hline \multicolumn{2}{|c|}{$\begin{array}{l}\mathrm{R}^{2} \text { fixed }=0.158, \mathrm{R}^{2} \text { random }=0.413, \mathrm{~N}=6522 \text { tokens, } 41 \text { speakers }(\mathrm{sex}=\mathrm{F}) \\
\text { log-likelihood }-3243.645 . \text { Random: Speaker, Following vowel }\end{array}$} \\
\hline \multicolumn{2}{|c|}{ Men only } \\
\hline Factors & Log-odds \\
\hline Combined Index n.s. & $\mathrm{n} / \mathrm{a}$ \\
\hline $\operatorname{Age}^{* * *}(p=0.0002)$ & 0.068 , that is, $7.0 \%$ higher odds of retroflex per year older \\
\hline $\begin{array}{l}\mathrm{R}^{2} \text { fixed }=0.147, \mathrm{R}^{2} \text { ra } \\
\text { log-likelihood }-3348 \text {. }\end{array}$ & $\begin{array}{l}\text { dom }=0.413, N=6819 \text { tokens, } 43 \text { speakers }(\operatorname{sex}=\mathrm{M}) \\
\text { Random: Speaker, Following vowel }\end{array}$ \\
\hline
\end{tabular}

We conclude that Ganluo Ersu speakers' use of retroflexes is dramatically declining in apparent time, and we find that our Combined Index (a socioeconomic status index combining occupation and education) and sex are significant factors as well. This change in the direction of Southwestern Mandarin can be characterized as contactinduced socially constrained variation. Speakers with higher SES tend to produce less retroflexes, but this effect is gendered: Regression analyses of women-only and menonly datasets suggest that women's retroflexes are best modeled by the Combined Index, while men's retroflexes are best modeled by age. Why? Sociologically, our demographic analyses in this section have shown that Ganluo women's socioeconomic statuses are increasing in apparent time more rapidly than men's. As China's reform era blossomed in the late 1970s and early 1980s, women started out on lower rungs of the socioeconomic scale than men did, and so women have had a much steeper climb. With this social context, it is not surprising that socioeconomic status is a stronger predictor for women than for men. The results are consistent with Labov's principle that women favor incoming prestige forms (1990:213-4, 2001:261293), and those gendered linguistic effects are especially salient here due to the acute change-in-progress in women's social status. In the Discussion, we will also consider 
these results in terms of gendered responses to covert/overt prestige, as well as other related prior work.

\section{Other variables}

In this section we consider (a) delateralization of the voiceless lateral fricative, (b) devoicing of stops/affricates, and (c) consonant onset simplification, all of which are typical for the speech of younger speakers.

Delateralization of the voiceless lateral fricative. We observe that the voiceless lateral fricative is delateralized and pronounced as $[\mathrm{x}]$ by many speakers. For example: [lá $] \sim[\mathrm{x}]$ 'month'. We will examine delateralization with the same social factors.

Age

In Figure 10, we plot the percentage of Ganluo Ersu laterals as a function of age, dividing in terms of women (dark dots) and men (gray triangles). Graphically, we observe an overall trend toward lower percentages of lateral realizations for younger speakers. ${ }^{8}$ 


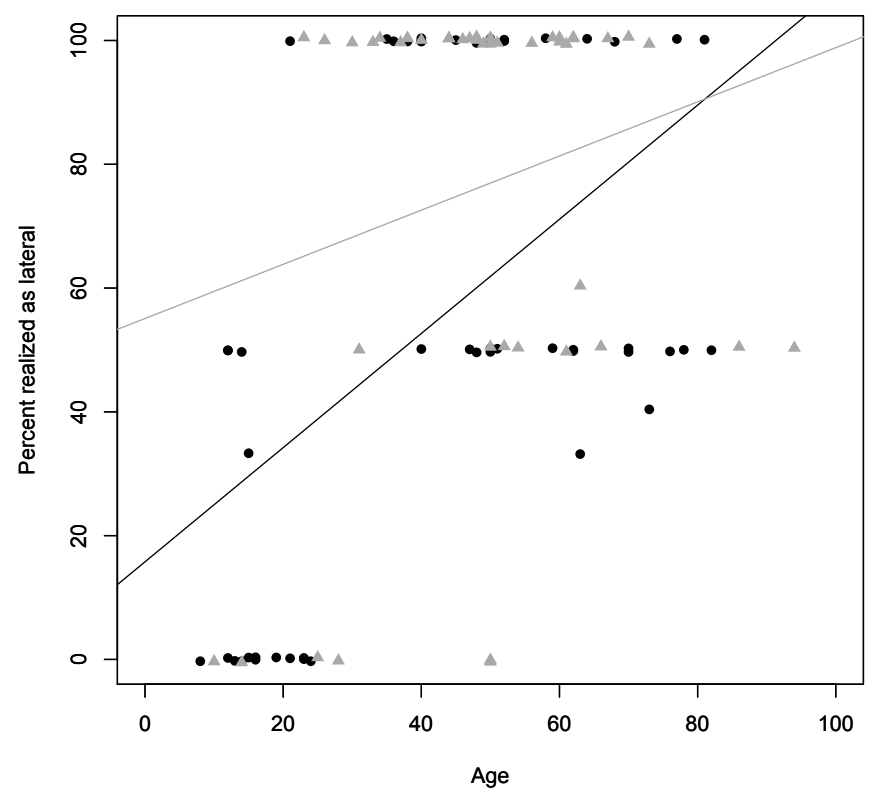

FIgURE 10. Percent of laterals versus age. Dark dots=women, $0.922 \%$ per year, $\mathrm{R}^{2}=0.268, \quad p<0.0001,52$ female speakers. Gray triangles $=$ men, $\mathrm{R}^{2}=0.043$, n.s. $(p=0.175), 44$ male speakers. Jitter added.

\section{Multivariate analysis of delateralization}

The dataset for lateral fricatives is more modest than the retroflex dataset (387 tokens from 96 speakers) since only six words contain a segment that may be realized as a lateral fricative.

The logistic regression testing age, sex, and SES (Combined Index) finds sex alone is significant: Female speakers have log-odds -0.753 or $52.9 \%$ lower odds of producing a lateral. But it is not a strong model, as $\mathrm{R}^{2}$ is only 0.056 . We obtain more meaningful results by including the children. As explained in the retroflex section above, when we include children in the model, we only test for age and sex (not educational or occupational factors). For the dataset including children, the multiple regression best-fit model shows both age and sex are significant (Table 7). Consistent with Figure 10, Table 7 shows that speakers' production of the lateral voiceless fricative is modeled as $5.8 \%$ higher odds for each year older, and $57.5 \%$ lower odds for women. 
TABLE 7. Lateral fricatives: logistic regression results (best-fit model), including children

\begin{tabular}{|l|l|}
\hline Age $^{* * *}(p<0.0001)$ & $\begin{array}{l}\text { Log-odds: } 0.057, \text { that is, } 5.8 \% \text { higher odds of lateral } \\
\text { per year older }\end{array}$ \\
\hline Sex & $* * *(p=0.0117)$ \\
\hline Age:Sex & $\begin{array}{l}\text { Log-odds: }-0.855, \text { that is, } 57.5 \% \text { lower odds of lateral } \\
\text { for women }\end{array}$ \\
\hline $\begin{array}{l}\mathrm{R}^{2} \text { fixed }=0.209, \mathrm{R}^{2} \text { random }=0.526, \text { log-likelihood }-217.3,387 \text { tokens, } 96 \text { speakers. } \\
\text { Random: speaker }\end{array}$ & n.s. \\
\hline
\end{tabular}

Conclusion for delateralization of the lateral voiceless fricative.

We conclude that delateralization of fricatives is increasing in apparent time, and this change is led by younger women. Unlike retroflexes, we do not find a socioeconomic effect for this variable, but we also note that the tokens available for modeling are more limited than the retroflex data in the previous section.

Devoicing of stops and affricates. We observe that younger speakers more likely to devoice stops and affricates, in accord with Mandarin phonology, which lacks voiced stops and affricates. Examples are given in (1). Figure 11 is a plot of the percentage of devoiced stops/affricates versus age.

$\begin{array}{ll}{[\text { dzà }] \sim[\text { tsà }]} & \text { 'paddy' } \\ {[\text { bć }] \sim[\text { pć }} & \text { 'insect' } \\ {[\text { dzó }] \sim[\text { tcó }]} & \text { 'push' } \\ {[\text { vá] } \sim[\text { fá }]} & \text { 'net' }\end{array}$




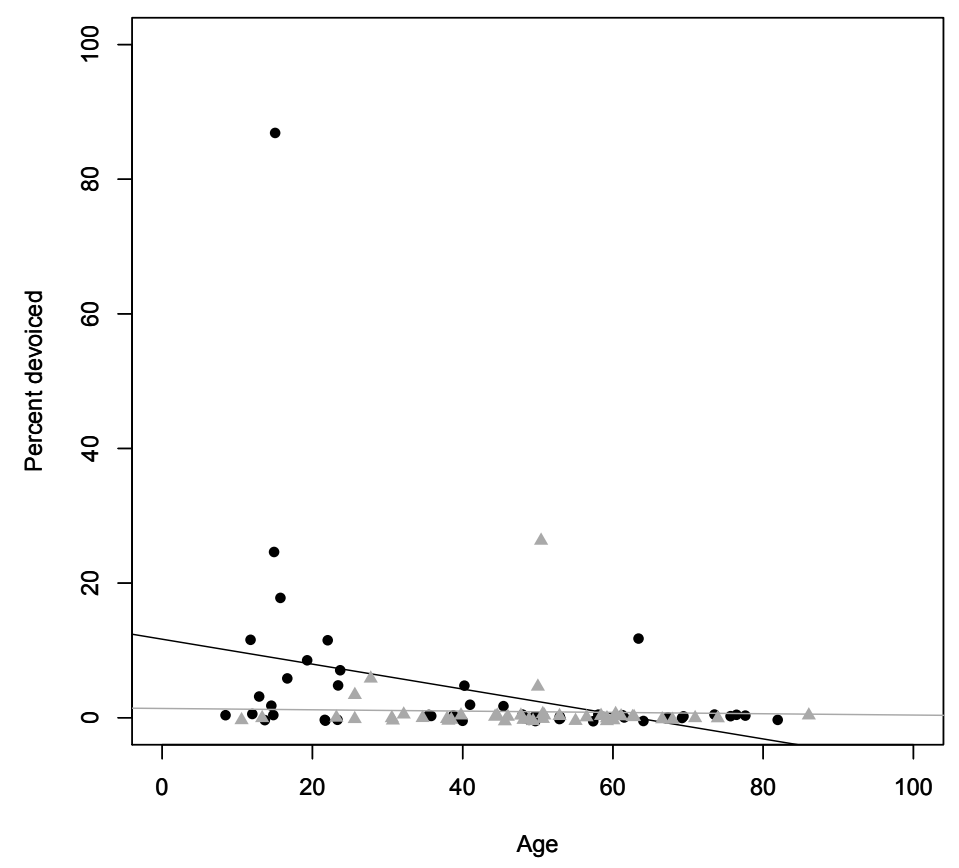

FIGURE 11. Percent of devoiced stops/affricates as a function of speaker age. Dark dots $=$ women, $-0.186 \%$ per year, $p=0.026, \mathrm{R}^{2}=0.097, \mathrm{~N}=51$. Gray triangles $=$ men, n.s., $p=0.807, \mathrm{R}^{2}=0.001, \mathrm{~N}=43$. Jitter added.

We use a logistic regression on individual tokens of stops and affricates to model the factors that contribute to devoicing. As before, we run the regression without children so that SES can be included in the model. In the best-fit model, no factors are significant predictors of devoicing (age, sex, SES, and their interactions). Next we run a regression with the children included using age and sex as factors. As Table 8 shows, the results are significant for age: the odds of devoicing stops and affricates increase $33.2 \%$ per year older. Note: the model tests 94 speakers rather than 98 speakers because four speakers did not have enough usable data for this variable.

TABLE 8. Devoicing of stops/affricates, including children: Logistic regression results (best-fit model)

\begin{tabular}{|l|l|}
\hline Age** $(p=0.0063)$ & Log-odds -0.104, that is, $33.2 \%$ lower odds per year older \\
\hline Sex, Age:Sex & n.s. \\
\hline $\begin{array}{l}\mathrm{R}^{2} \text { fixed }=0.152, \mathrm{R}^{2} \text { random }=0.700,6474 \text { tokens, } 94 \text { speakers } \\
\text { log-likelihood }-410.3, \text { Random: speaker, following vowel }\end{array}$ \\
\hline
\end{tabular}


Finally, because we observe a possible sex contrast in Figure 11, we run logistic regressions on women alone and men alone (Table 9). Among women, younger speakers are significantly more likely to use devoiced stops and affricates. For men, we find no significant factors.

TABLE 9. Devoicing of stops/affricates: Gendered logistic regression results (stepup/step-down), including children

\begin{tabular}{|l|l|}
\hline \multicolumn{2}{|c|}{ Women only } \\
\hline Factors: & Log-odds: \\
\hline Age $^{* * *}(p=0.0006)$ & -0.107, that is, $10.1 \%$ lower odds for each year older \\
\hline $\mathrm{R}^{2}$ fixed $=0.29, \mathrm{R}^{2}$ random $=0.51,3510$ tokens, 51 speakers (sex $\left.=\mathrm{F}\right)$ \\
log-likelihood -316.5. Random: Speaker, Following vowel \\
\hline \multicolumn{2}{c}{ Men only } \\
no significant factors, 2964 tokens, 43 speakers (sex $=\mathrm{M})$
\end{tabular}

\section{Conclusion for devoicing of stops and affricates}

Much like the delateralization variable in the previous section, the devoicing of stops and affricates is being led by younger women, and SES is not significant.

Simplification of onsets. Finally, we examine the simplification of onsets. Our word list has 22 words that contain complex onsets in conservative Ganluo Ersu, including prenasalized clusters, clusters with a schwa-like segment, and clusters with approximants (see section 1 Introduction). Examples are given in (2). The simplified forms are closer to Mandarin phonology, which does not have these complex onsets.

$$
\begin{aligned}
& \text { [mbò] [bò] 'horse' } \\
& \text { [mp } \left.{ }^{\mathrm{h}} \text { ó }\right] \sim\left[\mathrm{p}^{\mathrm{h}} \mathrm{ó}\right] \quad \text { 'steal' } \\
& \text { [Sótswá] [Jótsá] 'be new' } \\
& \text { [ətó ] [tó] 'jump' } \\
& \text { [əmह́ }] \sim[\mathrm{m} \varepsilon \dot{ }] \quad \text { 'soldier' } \\
& \text { [kwá] [ká] 'take off' }
\end{aligned}
$$

For each speaker, we calculate the percentage of simplified onsets by taking the number of simplified onsets divided by the number of total words that contain 
complex onsets in conservative Ganluo Ersu (Chirkova et al., 2015). Figure 12 plots this percentage versus speaker age, showing a steady increase of cluster simplification for younger speakers of both sexes. Tables 10-11 provide the results of multiple regression with and without children. We find that age is significant but no other factors are significant.

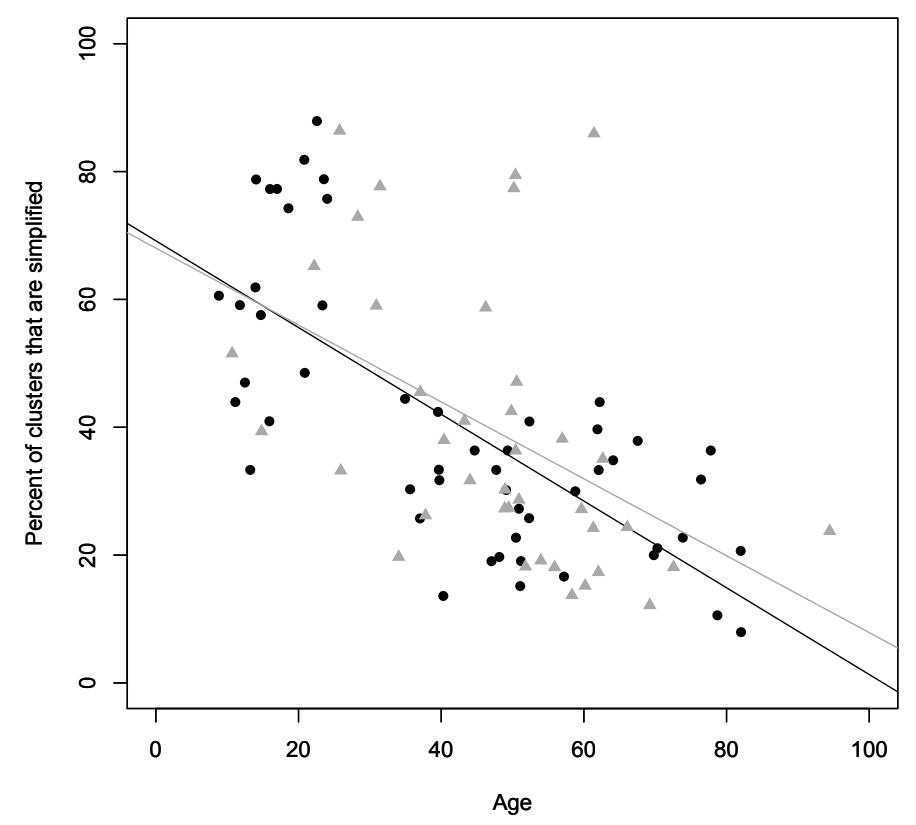

FIGURE 12. Percentage of simplified onsets as a function of speaker age, including children. Dark dots $=$ women, $p<0.0001,-0.68 \%$ per year, $\mathrm{R}^{2}=0.514, \mathrm{~N}=52$. Gray triangles $=$ men, $-0.60 \%$ per year, $p=0.0029, \mathrm{R}^{2}=0.215, \mathrm{~N}=39$. Jitter added.

TABLE 10. Onset simplification, not including children: Multiple regression results (best-fit model)

\begin{tabular}{|l|l|}
\hline Age $^{* * *}(p<0.0001)$ & Coefficient: 0.008, that is, $0.8 \%$ higher per year younger \\
\hline $\begin{array}{l}\text { Sex, age, SES, and } \\
\text { interactions }\end{array}$ & n.s. \\
\hline $\mathrm{R}^{2}=0.354, \log$-likelihood $-29.10,78$ speakers \\
\hline
\end{tabular}

Table 11. Onset simplification, including children: Multiple regression results (best-fit model).

\begin{tabular}{|l|l|}
\hline Age $* * *(p<0.0001)$ & Coefficient: 0.006, that is, $0.6 \%$ higher per year younger \\
\hline Sex, age:sex & n.s. \\
\hline $\mathrm{R}^{2}=0.375, \log$-likelihood $-34.15,91$ speakers \\
\hline
\end{tabular}


In summary, we find that younger speakers are more likely to simplify consonant onsets, reducing them in the direction of Mandarin phonology. We do not find socioeconomic or sex effects in this variable.

\section{Overall summary}

Comparing the different types of variables (loss of retroflexes, delateralization of fricatives, devoicing of stops/affricates, onset simplification), we can summarize the results as follows. First, younger speakers are leading the changes in every case. Moreover, for delateralization of fricatives and devoicing of stops/affricates, younger women are the leaders. This is consistent with the Labovian principle that women lead changes from above (Labov, 2001:261-293). We also find that higher education and higher levels on Wang Dehe's occupational scale emerge as significant factors in the loss of retroflexes; specifically, the use of retroflexes decreases with each step higher on our Combined Index SES scale. In our retroflex analysis, there are interactions between sex, socioeconomic status, and age. Women's use of retroflexes is best predicted by socioeconomic status (speakers with lower SES use more retroflexes), while men's retroflexes are best predicted by age (older speakers use more retroflexes). Sociologically, our results suggest that Ganluo Ersu women have undergone a more dramatic change in socioeconomic status than men during China's changes in recent decades. We suggest that this gendered difference in socioeconomic change underlies the gendered contrast: Across ages, higher socioeconomic status women are more likely to avoid retroflexes than lower socioeconomic status women. Similar to Labov (2001:261-293), Trudgill (1972, 1974) and other classic work, Ganluo Ersu women are leading a change from above. Moreover, in Ganluo social 
status is an especially salient factor for women since they have experienced the greatest change in this regard. These core findings are further interpreted next.

\section{DISCUSSION}

In this study we documented and analyzed patterns of consonant variation among 97 speakers of Ganluo Ersu. Focusing on four distinct variables (loss of retroflexes, delateralization of the lateral voiceless fricative, devoicing of stops/affricates, and simplification of consonant onsets), we found evidence of change in progress in all cases. In each case, younger speakers are shifting their pronunciation away from the more conservative Ganluo Ersu of their elders. For each variable, we noted that the sound changes are in the direction of Southwestern Mandarin. Integrating these observations with evidence from earlier work on Ersu and Southwestern Mandarin, we interpreted these Ganluo Ersu changes to be a case of Mandarin-induced phonological convergence. Moreover, we found that these changes are occurring in a socially stratified way.

Overall, the results reflect the transition from an earlier setting of multilingualism with relatively equal prestige among languages (Ersu-NuosuMandarin) to one with an unequal relationship between the indigenous minority language (Ersu) and the dominant, majority language (Mandarin). In the modern era, rural minorities all over China associate Mandarin with economic gain, power, prestige, and upward mobility (Tsung, 2012; Van den Berg \& Xu, 2010; Zhou, 2012; $\mathrm{Xu}, 2010)$. Language choice, interrelated in complex ways with occupation and education, plays an important part in the process of change in Ersu. In particular, our field observations and ethnographic interviews suggest that greater exposure and assimilation to Mandarin Chinese is manifested through higher education and higher 
status occupations. As with other cases of language shift, we find that Mandarin is progressing through domains of use (recall Table 3).

These dramatic changes naturally do not go unnoticed by the Ersu community. In our interviews, the vast majority of speakers find that Ersu has low prestige and is under growing pressure from the neighboring languages. They also note a decrease in the range of contexts in which Ersu is used and express concern about the future of the language. Examples (3-5) have been translated into English:

(3) Older people speak best. ... The generation of grandchildren does not speak too well. They study, so they don't speak Ersu very well. They only speak Ersu at home, while outside they only speak Mandarin. - 77 year-old woman, illiterate, farmer

(4) Good Ersu is spoken by people around the age of 50-60. Their language is the best ... Young people nowadays mostly study away from their home villages where they mostly speak Mandarin. - 46 year-old man with elementary school education

(5) Older people speak more standard Ersu; the younger the speaker, the less standard the language they speak. - 40 year-old woman, university graduate, teacher

Younger Ersu speakers are most affected by Mandarin pronunciations, leading the changes toward Mandarin phonology in every variable. This is consistent with findings on children's ethnic socialization (e.g., Phinney \& Rotheram, 1987). When children enter the domains of schooling and national culture, they tend to rapidly reject the use of their community (indigenous) language. This is largely the result of a sensitivity of school-age children and adolescents to the valorization of the dominant majority language (e.g., Anderson, 2012:8; Heller, 1987).

Interestingly, the observed variation (the four variables examined in our study) carries its weight of social meaning in terms of a prestige contrast with Mandarin, while retaining a different social meaning within Ersu itself. That is, Mandarininfluenced Ersu pronunciations are associated with dominant Chinese culture and the prestige of upward mobility, but there is still a sense that conservative forms of Ersu 
are "better." This creates a contrast between locals" appreciation of who "speaks better" and the communal change in progress toward more Chinese-influenced forms. Recalling the interview questions listed in Methods, we find that the vast majority of speakers agree that (a) the Ersu language as spoken by older people is the most "pleasing to the ear," (b) middle-aged people speak less well, (c) young people yet less well, and (d) the Ersu as spoken by children is the least "correct."

Our data led us to examine the question "In what ways are Labovian principles relevant to endangered minority languages?" We considered our Ganluo Ersu field data in comparison to classic sociolinguistic patterns (e.g., Labov, 1966, 1991[1972], 2001), including social stratification, age, sex, prestige, and gendered changes in progress. In variables where sex has a significant role, it is the young women who are leading the change toward a more prestigious - more Mandarin-like-pronunciation. This is consistent with Labov's principles on gendered differences (e.g., 1990:213-4, 2001:261-93). We also find an interesting interaction between sex and socioeconomic status in the loss of retroflexes. Retroflexes are decreasing with each step higher on the SES Combined Index. Further, when we divide our dataset into men and women and test for socioeconomic status effects on the two separate groups, we see that SES is significant for women but not men. Ganluo Ersu women with higher social status are avoiding the use of retroflexes, thus positioning themselves more closely with the pronunciation of Southwestern Mandarin, which does not have these retroflexes. This is consistent with the classic sociolinguisic principle that women tend to use more standard forms than men (e.g., Trudgill, 1974), and to lead change to a more prestigious language in situations of language shift (e.g., Gal, 1979). By contrast, the Ganluo Ersu men's retroflexes are predicted by age alone; younger men use fewer retroflexes, and social status is not a predictor for men's retroflexes. This is also 
consistent with prior observations that men often have greater loyalty to the conservative language norms of the community (e.g., Chambers \& Trudgill, 1980; Lippi-Green, 1989; Romaine, 2003). As a result, simple age is the strongest factor for the men's retroflexes. Ganluo Ersu women's greater preference for prestige forms therefore matches the Labovian prediction for change from above (1990:213-4; 2001:261-293).

Moreover, the greater influence of socioeconomic status on Ganluo women can also be understood in terms of gendered sociological changes in China. As China has undergone major socioeconomic changes in recent generations, women's lives have been altered more dramatically than men's. Prior to Deng Xiaoping's era of sociopolitical reform, women had far lower educational levels and occupational opportunities than men, so the changes have been more dramatic for them. Gendered sociolinguistic patterns emerging from such differentiated socioeconomic circumstances have been reported in major languages, such as German and Hungarian (Gal, 1979), Brazilian Portugese (Bortoni-Ricardo, 1985), German dialects (LippiGreen, 1989), and English (Cheshire, Kerswill, Fox, \& Torgerson, 2011; Milroy, 1980). As for smaller indigenous languages, Brunelle (2009) reports on a phonological variation in Eastern Cham of Vietnam that is sociolinguistically gendered for similar reasons.

This Ganluo Ersu study is the first variationist account of change in progress in a Tibetan-Burman language of Sichuan province. Our interpretation of the results may benefit from comparison to a related study: Jamsu Reynolds' (2012) work on Amdo Tibetan of Qinghai province. Focusing on Amdo nasal variation in contact with Mandarin Chinese, Reynolds finds that age, sex, and Tibetan written literacy are significant factors. Although the study does not address socioeconomic stratification 
in terms of occupation, the unequal relationship between Amdo Tibetan and Mandarin offers some similarities with our Ersu study. Like Ersu, Reynolds finds sound changes in the direction of Mandarin-influenced pronunciations. Unlike Ersu, written Tibetan is actively used in the Amdo community of Reynold's study. Reynolds finds that literacy in written standard Tibetan is an important factor counteracting the contactinduced change in Amdo Tibetan: Illiterate speakers are leveling their nasal pronunciation in the direction of Mandarin (a nasal merger), but speakers with more education tend to resist the contact-induced shift toward Mandarin. For Ganluo Ersu, the lack of a written language facilitates the spread of convergent changes. In the Ganluo community, the only written language in use is Mandarin.

\section{CONCLUSION}

The small rural Ersu Tibetan community of Ganluo, Sichuan, is a long way from New York City: geographically, linguistically, and culturally. At first glance, a researcher might suppose that the classic Labovian principles formulated in Western, urban, industrialized environments would not be relevant in any way. However, we find that as Ganluo undergoes ever-increasing contact with a locally prestigious language and culture (Chinese), Labov's classic principles are relevant as the ongoing phonological convergence manifests itself in a socially stratified way. This suggests a generalizable, testable principle relevant to minority languages undergoing contact with dominant majority languages. We call this the principle of contact-induced sociolinguistic stratification: When a minority language undergoes linguistic convergence toward a majority language due to intense social and linguistic contact with the majority community, this convergence is manifested in a socially stratified way that is consistent with many of the predictions of classic sociolinguistic 
principles. Naturally, we expect the details to play out differently due to different localized cultural circumstances. But our Ersu study suggests that some of the broad outlines of the Labovian principles are evident in these intensive contact settings.

Maybe Ganluo Ersu is not so far away after all. 


\section{Notes}

1. Ersu alveolar affricates are produced with the tongue touching the middle of the alveolar ridge (laminal alveolar). They are notated as /țs ț̣ ${ }^{\mathrm{h}}$ dụ/ in Chirkova et al. (2015), which we use as basis for our transcriptions. For readability, Ersu alveolar affricates are here represented by the IPA symbols $/ \mathrm{t} \int \mathrm{t} \int^{\mathrm{h}} \mathrm{d} z /$.

2. The historical Chinese variety of the Sui (581-618 CE) and Tang (618-907 CE) dynasties, as documented in contemporary sources, most importantly the Qieyun 切韵 , a rime dictionary by Lu Fayan 陆法言, published in $601 \mathrm{CE}$.

3. In Ganluo, the Ersu people traditionally live in the northwestern part of the county—-that is, northwest of Niri River (尼日河)—in the townships of Liaoping (蓼 坪乡), Zela (则拉乡), Tuanjie (团结乡), Pingba (坪坝乡), and in the towns of Yutian (玉田镇) and Haitang (海棠镇) (Munai, 2015:4; Wang, 2010:4). In addition, since the 1970s-1980s there is a sizeable Ersu-community of some 1,500 people in the newly created Xinshiba Town (新市坝镇) in the central part of Ganluo county, in the vicinity of the county seat. Other parts of the county are populated by Nuosu and Chinese.

\section{4. https://elar.soas.ac.uk/Collection/MPI655457}

5. An anonymous reviewer suggests an additional possibility for enriching the existing dataset by relating individual speakers' language choice during the Q\&A section of the interview to the use of Ersu and Mandarin across different functional domains (as in Table 3 below). Regrettably, we could not implement this suggestion, because language choice during the Q\&A section depended on the co-author Wang Dehe rather than on the interviewee; we do not have information on language preferences of different interviewees. According to Wang Dehe, their language choice would be Ersu in the majority of cases. That is because all Ersu people reportedly 
have a strong sense of loyalty toward their group and language and would use Ersu when communicating with their community members.

6. The interview data are not directly comparable due to different duration and different topics covered, which precluded precise quantification of results. All interview data are made available at ELAR for further exploration.

7. The relationship between Ersu and Chinese is not diglossic (Ferguson, 1959; Fishman, 1967) because Chinese is rapidly encroaching, not stable.

8. Because there are only six relevant words for the lateral fricative variable in the word list, the distribution is clustered around a few levels: $0,50,100 \%$, reflecting $0 / 6$, $3 / 6$, and $6 / 6$ respectively, with a handful of other speakers scoring on the $33 \%$ level $(2 / 6)$ or $66 \%(4 / 6)$ levels or other percentages if a speaker failed to produce one of the six relevant tokens. 


\section{REFERENCES}

Anderson, Gregory D. S. (2012). Language hotspots: What (applied) linguistics and education should do about language endangerment in the twenty-first century. In L. Cope (ed.), Applied Linguists Needed: Cross-disciplinary Teamwork in Endangered Language Contexts. London \& New York: Routledge. 7-24.

Ash, Sharon. (2013). Social class. In J.K. Chambers \& N. Schilling (eds.), The handbook of language variation and change. Malden, Massachusetts: WileyBlackwell. 350-367.

Bortoni-Ricardo, Stella M. (1985). The urbanization of rural dialect speakers: A sociolinguistic study in Brazil. Cambridge Studies in Linguistics. Cambridge: Cambridge University Press.

Bradley, David. (1997). Tibeto-Burman languages and classification. In D. Bradley (ed.), Tibeto-Burman languages of the Himalayas (Papers in Southeast Asian Linguistics no.14). Canberra: Department of Linguistics, Research School of Pacific and Asian Studies, Australian National University. 1-71.

Brunelle, Marc. (2009). Diglossia and monosyllabization in Eastern Cham: A sociolinguistic study. In J. N. Stanford \& D. R. Preston (eds.), Variation in indigenous minority languages. Amsterdam \& Philadelphia, PA: John Benjamins Publishing Company. 47-76.

Bucholtz, Mary. (1999). “Why be normal?” Language and identity practices in a community of nerd girls. Language in Society 28:203-23.

Chambers, J.K., \& Peter Trudgill. (1980). Dialectology. Cambridge: Cambridge University Press.

Cheshire, Jenny, Paul Kerswill, Susan Fox, \& Eivind Torgersen. (2011). Contact, the feature pool and the speech community: The emergence of Multicultural 
London English. Journal of Sociolinguistics 15:151-196.

Chirkova, Katia. (2012). The Qiangic subgroup from an areal perspective: A case study of languages of Muli. Language and Linguistics 13.1:133-170.

Chirkova, Katia. (2014). The Duoxu Language and the Ersu-Lizu-Duoxu Relationship. Linguistics of the Tibeto-Burman Area 37.1:104-146.

Chirkova, Katia, Dehe Wang, Yiya Chen, Angélique Amelot, \& Tanja Kocjančič Antolík. (2015). Ersu. Illustrations of the IPA. Journal of the International Phonetic Association 45.2:187-211.

Clarke, Sandra. (2009). Sociolinguistic stratification and new dialect formation in a Canadian aboriginal community: not so different after all? In: J. N. Stanford \& D. R. Preston (eds.), Variation in indigenous minority languages. Amsterdam \& Philadelphia, PA: John Benjamins Publishing Company. 109-128.

Clyne, Michael. (2003). Dynamics of language contact: English and immigrant languages. Cambridge Approaches to Language Contact. Cambridge: Cambridge University Press.

Coupland, Nikolas. (2001). Language, situation, and the relational self. In P. Eckert \& J. Rickford (eds.) Style and sociolinguistic variation. Cambridge: Cambridge University Press. 185-210.

Dodsworth, Robin. (2011). Social class. In R. Wodak, B. Johnstone \& P. Kerswill (eds.), The SAGE handbook of sociolinguistics. Los Angeles/London: SAGE. 192-207.

Eckert, Penelope. (1997). Age as a sociolinguistic variable. In F. Coulmas (ed.), The handbook of sociolinguistics. Malden, MA: Blackwell. 
Eckert, Penelope. (2001). Style and social meaning. In P. Eckert \& J. R. Rickford (eds.), Style and sociolinguistic variation. Cambridge: Cambridge University Press. 119-127.

Eckert, Penelope. (2012). Three waves of variation study: The emergence of meaning in the study of sociolinguistic variation. Annual Review of Anthropology 41:87-100.

Eckert, Penelope, \& Sally McConnell-Ginet. (1992). Think practically and look locally: Language and gender as community-based practice. Annual Review of Anthropology 21:461-90.

Ferguson, Charles. (1959). Diglossia. Word 15.2:325-40.

Fishman, Joshua. (1967). Bilingualism with and without diglossia; diglossia with and without bilingualism. Journal of Social Issues 23.2:29-38.

Fishman, Joshua. (1991). Reversing language shift: Theoretical and empirical foundations of assistance to threatened languages. Clevedon, UK \& Philadelphia, PA: Multilingual Matters.

Gal, Susan. (1979). Language shift: Social determinants of linguistic change in bilingual Austria. Academic Press.

Gao, Katie. (2017). Dynamics of language contact in China: Ethnolinguistic diversity and variation in Yunnan. Doctoral dissertation, University of Hawaii.

Gilroy, Paul. (1995). The status of difference: From epidermalization to nano-politics. Critical Urban Studies: Occasional Papers, CUCR, Goldsmith’s College.

Grenoble, Lenore \& Lindsay Whaley (Eds). 1998. Endangered languages: Language loss and community response. Cambridge: Cambridge University Press.

Groves, Paula. (2003). Insider, outsider, or exotic other? Identity, performance, reflexivity, and postcritical ethnography. In G. G. Generett \& R. B. Jeffries 
(Eds.), Black women in the field: Experiences understanding ourselves and others through qualitative research, Cresskill, NJ: Hampton. 103-115.

Guy, Gregory. (1988). Language and social class. In F. Newmeyer (Ed.), Linguistics: The Cambridge survey, volume 4: The sociocultural context. Cambridge: Cambridge University Press. 37-63.

Heller, Monica. (1987). The role of language in the formation of ethnic identity. In J. Phinney \& M.J. Rotheram (Eds.), Children's ethnic socialization: Pluralism and development. Newbury Park, CA: Sage. 180-200.

Hopper, Paul. (2007). Understanding cultural globalization. Cambridge: Polity Press. Jamsu Reynolds, Jermay. (2012). Language variation and change in an Amdo village: Gender, education and resistance. Doctoral dissertation, Georgetown University.

Johnson, Daniel. (2009). Getting off the GoldVarb Standard: Introducing Rbrul for Mixed-Effects Variable Rule Analysis. Language and Linguistics Compass, 3.1:359-383.

Johnstone, Barbara. (2004). Place, globalization, and linguistic variation. In C. Fought (Ed.), Sociolinguistic variation: Critical reflections. New York: Oxford University Press. 65-83.

King, Ruth. (1989). On the social meaning of linguistic variability in language death situations: Variation in Newfoundland French. In N. C. Dorian (Ed.), Investigating obsolescence: Studies in language contraction and death. Cambridge: Cambridge University Press. 139-148.

Labov, William. (1963). The social motivation of a sound change. Word 19:273-309. Labov, William. (1966). The social stratification of English in New York City. Washington: Center for Applied Linguistics. 
Labov, William. (1990). The intersection of sex and social class in the course of linguistic change. Language Variation and Change 2:205-254.

Labov, William. (1991) [1972]. Sociolinguistic patterns. Philadelphia, Pennsylvania: University of Pennsylvania Press. [The Social Stratification of (r) in New York Department Stores. 43-54.]

Labov, William. (1994). Principles of linguistic change. Vol. 1: Social Factors. Oxford: Blackwell.

Labov, William. (2001). Principles of linguistic change. Oxford \& Cambridge, MA: Blackwell.

Labov, William. (2016). Afterward: Where are we now? Journal of Sociolinguistics 20.4:581-602.

Ladefoged, Peter \& Ian Maddieson. 1996. The sounds of the world's languages. Malden MA: Blackwell Publishers.

Lee, Wai-Sum \& Eric Zee. 2003. Standard Chinese (Beijing). Illustrations of the IPA. Journal of the International Phonetic Association 33.1:109-112.

Levon, Erez. (2015). Integrating intersectionality in language, gender, and sexuality research. Language and Linguistics Compass 9:295-308.

Li, Yuming \& Wei Li. (2015). The language situation in China. Volume 3. Boston \& Berlin: Walter de Gruyter \& Beijing: The Commercial Press.

Li, Min \& Ming Ma. (1983). Liangshan Yiyu yuyin gailun [Introduction to the phonetics of the Yi language of Liangshan Prefecture]. Chengdu: Sichuan Nationalities Press.

Lippi-Green, Rosina. (1989). Social network integration and language change in progress in an alpine rural village. Language in Society 18:213-234. 
Liu, Huiqiang. (1983) [2007]. Ersuyu gaikuang [An outline of the Ersu language]. In Sh. Li \& J. Liu (eds.), Ersu Zangzu yanjiu [Studies on the Ersu Tibetans]. Beijing: Minzu Chubanshe. 462-500. First published in 1983 in Sichuan sheng Minzu Yanjiusuo (Eds.), Minzu yanjiu lunwenji [Collected papers on minority languages], vol. 1.

Matras, Yaron. (2009). Language contact. Cambridge: Cambridge University Press.

Meyerhoff, Miriam \& James N. Stanford. (2015). The changing face of sociolinguistics with a global perspective. In D. Smakman \& P. Heinrich (eds.), Globalising sociolinguistics, New York: Routledge Press. 1-15.

Milroy, Lesley. (1980). Language and social networks. Oxford: Blackwell.

Munai, Reha. (2015). Ganluo xian Ersu Zangzu yuyan wenhua yanjiu / The research of Ersu language and culture in Ganluo county. Beijing: Minzu Chubanshe.

Norman, Jerry. (1999). Chinese. Cambridge Language Surveys. Cambridge: Cambridge University Press. First published in 1988.

Phinney, Jean S. \& M.J. Rotheram (eds). (1987). Children's ethnic socialization: Pluralism and development. Newbury Park, CA: Sage.

Poplack, Shana, Lauren Zentz \& Nathalie Dion. (2012). Phrase-final prepositions in Quebec French: An empirical study of contact, code-switching and resistance to convergence. Bilingualism: Language and Cognition 15.2:203-225.

Poplack, Shana, James A. Walker \& Rebecca Malcomson. (2006). An English "like no other"?: Language contact and change in Quebec. Canadian Journal of Linguistics 51:185-213.

Poplack, Shana \& Stephen Levey. (2010). Contact-induced grammatical change: A cautionary tale. In P. Auer \& J. E. Schmidt (Eds.), Language and space - An 
international handbook of linguistic variation: Volume 1 - Theories and methods. Berlin: Mouton de Gruyter. 391-419.

Rickford, John. (1986). The need for new approaches to social class analysis in sociolinguistics. Language \& Communication 6.3:215-21.

Romaine, Suzanne. (2003). Variation in language and gender. In J. Holmes \& M. Meyerhoff (eds.), The handbook of language and gender, Blackwell Publishing, Malden MA. 98-118.

Schmitt, Edwin A. (2011). Commodification in an Ersu Tibetan Village of Sichuan, China. MA Thesis, Oregon State University.

Schmitt, Edwin A. (2014). The History and Development of De-swiddening among the Ersu in Sichuan, China. Himalaya, the Journal of the Association for Nepal and Himalayan Studies 34.2:97-110.

Sichuan sheng Ganluo xian difangzhi bianzuan weiyuanhui [Editorial Committee of the Gazetters of Ganluo County, Sichuan Province] (eds.). (1996). Ganluoxian zhi [Gazetteers of Ganluo County]. Chengdu: Sichuan Renmin Chubanshe.

Stanford, James N. (2008). A sociotonetic analysis of Sui dialect contact. Language Variation and Change 20:409-450.

Stanford, James N. (2009). Clan as a sociolinguistic variable. In J. N. Stanford \& D. R. Preston (eds.) Variation in indigenous minority languages. Amsterdam \& Philadelphia, PA: John Benjamins Publishing Company. 463-484.

Stanford, James N. \& Dennis R. Preston (eds.). (2009). Variation in indigenous minority languages. Amsterdam \& Philadelphia, PA: John Benjamins Publishing Company.

Sun, Hongkai. (1982). Ersu (Duoxu) hua jianjie [An outline of Ersu (Duoxu)]. Yuyan Yanjiu [Linguistic Study] 2:241-264. 
Sun, Hongkai. (1983). Liujiang liuyu de minzu yuyan ji qi xishu fenlei [Minority languages of the Six River Valley and their genetic classification]. Minzu Xuebao [Scholarly Journal of Nationalities] 3:99-274.

Sun, Hongkai. (2001). Lun Zang-Mian yuzu zhong de Qiang yuzhi yuyan [On the Qiangic branch of the Tibeto-Burman language family]. Language and Linguistics 2.1:157-181.

Thomason, Sarah Grey. (2001). Language contact: An introduction. Washington, DC: Georgetown University Press.

Thomason, Sarah Grey. (2008). Social and linguistic factors as predictors of contactinduced change. Journal of Language Contact 2.1:42-56.

Thomason, Sarah Grey. (2009). Contact explanations in linguistics. In R. Hikey (ed.), The handbook of language contact. Malden MA \& Oxford: Blackwell Publishers. 31-47.

Thomason, Sarah Grey \& Terrence Kaufman. (1988). Language contact, creolization, and genetic linguistics. Berkeley, Los Angeles \& Oxford: University of California Press.

Torres Cacoullos, Rena \& Catherine Travis. (2010). Testing convergence via codeswitching: Priming and the structure of variable subject expression. International Journal of Bilingualism 15.3:241-67.

Torres Cacoullos, Rena \& Catherine Travis. (2015). Gauging convergence on the ground: Code-switching in the community. International Journal of Bilingualism 19.4:365-86.

Torres Cacoullos, Rena \& Catherine Travis. (2016). Two languages, one effect: Structural priming in code-switching. Bilingualism: Language and Cognition 19.4:733-53. 
Tsunoda, Tasaku. (2006). Language endangerment and language revitalization: An introduction. The Hague: Mouton de Gruyter.

Tsung, Linda. (2012). Language and power: Tuanjie hua, an Yi-Han mixed language. International Journal of the Sociology of Language 215:63-77.

Trudgill, Peter. (1972). Sex, covert prestige and linguistic change in the urban British English of Norwich. Language in Society 1:179-195.

Trudgill, Peter. (1974). The Social Differentiation of English in Norwich. Cambridge: Cambridge University Press.

Van den Berg, Marinus \& Daming Xu. (2010). Industrialisation and the restructuring of speech community in China and Europe. Newcastle: Cambridge Scholars.

Wang, Dehe. (2010). Ersu Zangzu Wenhua Yanjiu [Study of Ersu Tibetan culture]. Chengdu: Sichuan University Press.

Winford, Donald. (2003). An introduction to contact linguistics. Malden, MA: Blackwell Publishers.

Wu Da. (2004). Choosing identities: The construction of ethnic identities among the Ersu of Sichuan. Doctoral Dissertation, The Chinese University of Hong Kong.

Wu Da. (2015). Three tongues and two identities: A case study of Ersu ethnic identities in Sichuan, China. Cultural Diversity in China 1.1:44-67.

$\mathrm{Xu}$, Daming. (2010). The formation of a speech community: Mandarin nasal finals in Baotou. In $\mathrm{M}$. Van den Berg \& $\mathrm{D}$. Xu (eds.), Industrialisation and the restructuring of speech community in China and Europe, Newcastle: Cambridge Scholars. 120-40.

Yuan, Jiahua. (2001). Hanyu fangyan gaiyao [Outline of Chinese dialects]. Beijing: Yuwen Chubanshe. First published in 1960, Beijing: Wenzi Gaige Chubanshe. 
Zhang, Sihong. (2013). A reference grammar of Ersu: A Tibeto-Burman language of China. Doctoral Dissertation, James Cook University.

Zhou, Minglang (ed.). (2012). The contact between Putonghua and minority languages of China. International Journal of the Sociology of Language, Special issue 215. 


\section{APPENDIX}

Word List

\begin{tabular}{|c|c|c|c|}
\hline & $\begin{array}{l}\text { Ganluo Ersu } \\
\text { (conservative) }\end{array}$ & English & Chinese \\
\hline 1 & tsth $^{\mathrm{h} o ́}$ & human being & 人 \\
\hline 2 & mé & ink & 墨水 \\
\hline 3 & ttré & steelyard & 秤 (一杆秤) \\
\hline 4 & tó & cliff & 崖（石崖） \\
\hline 5 & wá & Chinese yam & 山药 \\
\hline 6 & t t ${ }^{\mathrm{h}}$ & wild pepper & 花椒 \\
\hline 7 & tssó & feed & 喂 \\
\hline 8 & $\mathrm{ddz} \bar{n}^{\varepsilon}-\int^{\prime}$ & molar & 白齿 \\
\hline 9 & $\mathrm{~b} \varepsilon \dot{\varepsilon}$ & insect & 虫子 \\
\hline 10 & tssó & heap, pile up & 堆积 \\
\hline 11 & drò & pot, pan & 锅 \\
\hline 12 & dzà & paddy rice & 稻子 \\
\hline 13 & tfá & chase & 追（上） \\
\hline 14 & fá & month & 月 \\
\hline 15 & ndzzátsá & belt & 腰带 \\
\hline 16 & trá & line & 行 (数字) \\
\hline 17 & lá & fertilizer, manure & 肥料 \\
\hline 18 & ndáŕ́ & rice gruel & 稀饭 \\
\hline 19 & jó & sheep & 绵羊 \\
\hline 20 & tcà-tcá & squeeze & 夹 \\
\hline 21 & $\mathrm{k}^{\mathrm{há}}$ & barley & 大麦 \\
\hline 22 & dzzò & lay bricks & 砌 \\
\hline 23 & gá & sing & 唱（歌） \\
\hline 24 & tssútú & footprint & 脚印 \\
\hline 25 & J'tstswá & be new & 新（衣服） \\
\hline 26 & pý & potato & 洋芋 \\
\hline 27 & bátfá & knife & 刀 \\
\hline
\end{tabular}




\begin{tabular}{|c|c|c|c|}
\hline 28 & ízzá & son & 儿子 \\
\hline 29 & ná-tcá & $\begin{array}{l}\text { vow, pledge, } \\
\text { swear }\end{array}$ & 发誓 \\
\hline 30 & á & I & 我 \\
\hline 31 & dà-ttá & naughty & 淘气 \\
\hline 32 & léttú & bracelet & 手镯 \\
\hline 33 & $\grave{\mathrm{z}}$ & snow & 雪 \\
\hline 34 & dzó & push & 推 \\
\hline 35 & tssé & read & 读 \\
\hline 36 & yá & be hungry & 饿 \\
\hline 37 & $\mathrm{~d} \dot{\varepsilon}-\mathrm{t} \int^{\prime} \tilde{\varepsilon}$ & be sour & 酸 \\
\hline 38 & t fá & be sharp & 尖 \\
\hline 39 & $\dot{Y}^{\prime}$ & wine & 酒 \\
\hline 40 & $\operatorname{tr}^{\mathrm{h} h o ́}$ & $\operatorname{dog}$ & 狗 \\
\hline 41 & xá & have & 有 \\
\hline 42 & thó & to rot (of wood) & (木) 朽 \\
\hline 43 & ttá & star & 星星 \\
\hline 44 & $a^{\prime}$ & year & 年 \\
\hline 45 & tssú & bean & 豆子 \\
\hline 46 & ḑó & water & 水 \\
\hline 47 & làtfù & candle & 蜡烛 \\
\hline 48 & t'́ & one & 一 \\
\hline 49 & trú & sweat & 汗 \\
\hline 50 & dzú & poison & 毒 \\
\hline 51 & ot & count & 数（东西） \\
\hline 52 & dzú & sheep wool & 绵羊毛 \\
\hline 53 & drú & be dry & 干（衣服干了） \\
\hline 54 & əmé & soldier & 兵 \\
\hline 55 & tá & chicken & 鸡 \\
\hline 56 & $\operatorname{tr}^{\mathrm{h}} \mathrm{ó}$ & accent, speech & 腔 \\
\hline 57 & tà & get, obtain & 得到; 获得 \\
\hline
\end{tabular}




\begin{tabular}{|c|c|c|c|}
\hline 58 & ndzí-ndzí & quarrel & 吵架 \\
\hline 59 & vá & net & 网 \\
\hline 60 & náró & rib & 胁骨 \\
\hline 61 & ró & bone & 骨头 \\
\hline 62 & né & two & 二 \\
\hline 63 & ré & $\begin{array}{l}\text { land, nonirrigated } \\
\text { farmland }\end{array}$ & 地（旱地） \\
\hline 64 & tú & shave & 剃; 刮 \\
\hline 65 & $\stackrel{\mathrm{tsh}}{\mathrm{sh}}$ & lungs & 肺 \\
\hline 66 & kwá & take off & 脱（衣） \\
\hline 67 & táthá & mill, grindstone & 磨（水磨） \\
\hline 68 & วnદ́ & heavy & 重 \\
\hline 69 & tf ĥú-th'ú & mouth organ & 口琴 \\
\hline 70 & hkuàrá & circle, wheel & 旋转 (磨子旋转) \\
\hline 71 & léədá & arm & 胳膊 \\
\hline 72 & trhú-trthú & $\begin{array}{l}\text { rub, scratch an } \\
\text { itch }\end{array}$ & 蹭 \\
\hline 73 & tsthó & cough & 咳嗽 \\
\hline 74 & ódzá & pear & 梨 \\
\hline 75 & mjábó & tear & 眼泪 \\
\hline 76 & drà & drop, fall & 掉 \\
\hline 77 & ná-dá & cut with scissors & 剪（用剪刀剪） \\
\hline 78 & toó & turban; tie up & 头巾; 缠 \\
\hline 79 & mbò & horse & 马 \\
\hline 80 & dzá & tea & 茶 \\
\hline 81 & zú & oil & 油 \\
\hline 82 & tó & write & 写 \\
\hline 83 & dzźżá & enemy & 仇人 \\
\hline 84 & əzú & raise (chicken) & 养（鸡） \\
\hline 85 & dré & grind & 磨（面） \\
\hline 86 & tșá & fasten & 系=拴（腰带） \\
\hline 87 & trò & gallbladder & 胆（苦胆） \\
\hline
\end{tabular}




\begin{tabular}{|c|c|c|c|}
\hline 88 & dzí & tell & 告诉 \\
\hline 89 & วtș́ & interest & 利息 \\
\hline 90 & ndżz̀ & ride & 骑 \\
\hline 91 & $m p^{\text {hó }}$ & steal & 偷 \\
\hline 92 & dzù & waist & 腰 \\
\hline 93 & ndzé zó & owe money & 欠 (债) \\
\hline 94 & әра́⿱ & scatter, sprinkle & 撒（种子） \\
\hline 95 & róndré & Muya Tibetans & 木雅藏族 \\
\hline 96 & ndré & spear & 长矛 \\
\hline 97 & ətó & jump & 跳 \\
\hline 98 & ndrúpjé & skin & 皮肤 \\
\hline 99 & $\mathrm{t}^{\mathrm{h}} \mathrm{wá}$ & mule & 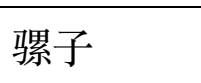 \\
\hline 100 & k à-t6à-tcá & $\begin{array}{l}\text { pick up [food } \\
\text { with chopsticks] }\end{array}$ & 夹 (菜) \\
\hline 101 & zúdzzá & fish bait & 鱼饵 \\
\hline 102 & yà-dzá & lie down & 躺 \\
\hline 103 & tá & flag & $\begin{array}{l}\text { 旗子 } \\
\end{array}$ \\
\hline 104 & tó & horn & 角 \\
\hline 105 & tfó & oats & 燕麦 \\
\hline 106 & né-tó & pick, pluck & 摘 \\
\hline 107 & drá-drá & transport & 运 (粮食) \\
\hline 108 & วt & excrement & 屎 \\
\hline 109 & ndzá-ndzá & change, exchange & 换（交换） \\
\hline 110 & drá & glutinous rice & 糯米 \\
\hline 111 & dzó-dzó & snatch & 抢 \\
\hline 112 & bý & wild cat & 野猫 \\
\hline 113 & téəná & shadow & 影子 \\
\hline 114 & tá & laugh & 笑 \\
\hline 115 & dzà & eat & 吃（饭） \\
\hline 116 & $\mathrm{nt} \int^{\text {h }}{ }^{2}$ & rice gruel & 稀饭 \\
\hline
\end{tabular}

